\title{
Responses of Macroinvertebrate Community Metrics to a Wastewater Discharge in the Upper Blue River of Kansas and Missouri, USA
}

\author{
Barry C. Poulton ${ }^{1 *}$, Jennifer L. Graham², Teresa J. Rasmussen ${ }^{2}$, Mandy L. Stone ${ }^{2}$ \\ ${ }^{1}$ U.S. Geological Survey, Columbia Environmental Research Center, Columbia, Missouri, USA \\ ${ }^{2}$ U.S. Geological Survey, Kansas Water Science Center, Lawrence, Kansas, USA \\ Email: *bpoulton@usgs.gov
}

Received 25 August 2015; accepted 17 October 2015; published 20 October 2015

Copyright (C) 2015 by authors and Scientific Research Publishing Inc.

This work is licensed under the Creative Commons Attribution International License (CC BY-NC). http://creativecommons.org/licenses/by-nc/4.0/

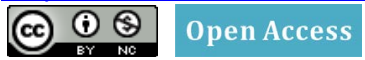

\begin{abstract}
The Blue River Main wastewater treatment facility (WWTF) discharges into the upper Blue River $\left(725 \mathrm{~km}^{2}\right)$, and is recently upgraded to implement biological nutrient removal. We measured biotic condition upstream and downstream of the discharge utilizing the macroinvertebrate protocol developed for Kansas streams. We examined responses of 34 metrics to determine the best indicators for discriminating site differences and for predicting biological condition. Significant differences between sites upstream and downstream of the discharge were identified for 15 metrics in April and 12 metrics in August. Upstream biotic condition scores were significantly greater than scores at both downstream sites in April $(p=0.02)$, and in August the most downstream site was classified as non-biologically supporting. Thirteen EPT taxa (Ephemeroptera, Plecoptera, Trichoptera) considered intolerant of degraded stream quality were absent at one or both downstream sites. Increases in tolerance metrics and filtering macroinvertebrates, and a decline in ratio of scrapers to filterers all indicated effects of increased nutrient enrichment. Stepwise regressions identified several significant models containing a suite of metrics with low redundancy $\left(R^{2}=\right.$ $0.90-0.99$ ). Based on the rapid decline in biological condition downstream of the discharge, the level of nutrient removal resulting from the facility upgrade $(10 \%-20 \%)$ was not enough to mitigate negative effects on macroinvertebrate communities.
\end{abstract}

\section{Keywords}

Macroinvertebrates, Metrics, Wastewater, Nutrients

\footnotetext{
${ }^{*}$ Corresponding author.
}

How to cite this paper: Poulton, B.C., Graham, J.L., Rasmussen, T.J. and Stone, M.L. (2015) Responses of Macroinvertebrate Community Metrics to a Wastewater Discharge in the Upper Blue River of Kansas and Missouri, USA. Journal of Water Resource and Protection, 7, 1195-1220. http://dx.doi.org/10.4236/jwarp.2015.715098 


\section{Introduction}

Streams flowing through heavily developed areas have received considerable attention in recent years because the human population is becoming more urban, and continued population growth will increase infrastructure needs [1]-[3]. It is estimated that by 2025 , more than $60 \%$ of the global population will be living in urban areas, and this estimate is even higher for Europe and the Americas [4] [5]. Stream corridors in urban landscapes have often been transformed into conduits altered to efficiently remove excess stormwater runoff from developed areas and as a conveyance for sediment and waste products [6]-[8]. However, urban waterways also provide valuable ecosystem services such as aesthetic and recreational opportunities, water supply for agriculture and industry, and disposal of wastewater from both municipal and industrial discharges [9]-[11]. In urban areas, residential property values are higher when streams or rivers are nearby, especially if the aesthetics of stream corridors are maintained [12] [13]. Urban streams are the foci for many outdoor activities, including education opportunities and intangible human values that are sometimes difficult to quantify [14]-[16].

Understanding of current stream conditions and the impacts of urbanization on those streams is critical for the protection and remediation of aquatic resources in both small and large metropolitan areas. Urbanization is the second leading cause of stream impairment in the U.S. [2] [17], and this land use change is known to negatively affect the ecology of streams at both small and large spatial scales [18]. Nutrient enrichment in the form of excess nitrogen and/or phosphorus is also a leading cause of stream impairment, in both Kansas [19] [20] and the U.S. as a whole [21]. Nutrient enrichment may cause nuisance algal growth in aquatic environments, which can lead to habitat degradation and secondary ecological effects such as substrate clogging or fouling [22]-[24], aesthetic concerns [25] [26], and decreased dissolved oxygen concentrations during organic matter decay [27][29]. Nutrient enrichment also can alter leaf-litter breakdown rates [30], food web components [31] [32], and stream metabolic processes such as nutrient attenuation, uptake, and assimilation rates [33]-[35]. Direct effects of excessive nutrient loading on aquatic organisms in streams can range from relatively benign increases in biomass or abundance, to more severe effects resulting in loss or displacement of indigenous taxa [36]. Specifically for aquatic macroinvertebrates, declines in sensitive species and loss of EPT (Ephemeroptera, Plecoptera, Trichoptera) taxa are among the most widely reported effects due to nutrient enrichment [2] [8] [37]-[39].

In rapidly urbanizing areas such as eastern Kansas, municipal wastewater treatment facilities (WWTF's) are one of the most common and prominent sources of excess nutrients in urban streams, and in many urban watersheds the discharges associated with these facilities may be the most significant point source [40] [41]. The Kansas Department of Health and Environment (KDHE) estimates that, among the major sources of water quality impairments in Kansas streams, 63\% of impaired stream miles in urban waterways are attributed to wastewater discharges, equating to approximately 805 stream miles [20]. However, these discharges provide the best opportunity to reduce nutrient loads in the environment because WWTF's can upgrade to new technologies that are available for nutrient removal [19]. Effects of WWTF discharges on stream macroinvertebrate communities have been documented in several studies, and include declines in total and EPT richness [42] [43], shifts to greater dominance of filtering taxa [44], and changes in abundance or diversity of specific functional feeding groups [45]-[47]. In addition, WWTF effluent can alter in-stream aquatic habitat [2] and food availability to terrestrial predators [48]. Wastewater discharges are also one of the main causes of noxious odors found in urban areas [49].

Macroinvertebrate community-level responses are commonly used for evaluating biological condition, longterm monitoring, diagnosis of specific sources and causes of stream impairment, measuring the success of restoration activities, and developing biological criteria in support of water quality compliance and regulation [50] [51]. Macroinvertebrate communities have also been widely used as an indicator of stream quality in urban watersheds [2] [37] [52]. Abundance and diversity information is used to calculate specific indicators representing community-level attributes (i.e. metrics) to describe the data. However, very few urban stream studies have included steps to identify combinations of metrics that best predict changes in biotic condition at the local (reach or segment) scale. Even though there is a wealth of information on effects of urbanization on aquatic communities and their habitats, specific responses of some macroinvertebrate indicator metrics to urban-related stressors have not been fully explored in these environments. Further, core macroinvertebrate metrics that state agencies use to evaluate stream impairment have similar responses to many different kinds of disturbances, and therefore may not be diagnostic enough to provide cause-effect relationships or identify clear pathways between degradation and indicator responses. Diagnosing the causes and sources of stream degradation in urban environments is 
especially difficult because these watersheds often have multiple co-occurring stressors [53] [54]. There is a need to identify metrics that are more diagnostic of degradation causes and to further characterize their responses in urban environments. Relatively few studies have examined specific reach-scale metric responses in an urban stream system where one clear point source of nutrients has the potential to impair a downstream reach. Even though upstream-downstream site comparisons represent one of the most simplistic approaches for characterizing these responses, it is likely that most stream systems flowing into urbanized areas that receive pointsource WWTF discharges have also experienced some degree of watershed-scale change in land use.

Some macroinvertebrate assessments have attempted to identify a suite of indicator response metrics that can be assembled into an integrated index such as the Invertebrate Community Index [55] [56] and the Benthic Index of Biotic Integrity (B-IBI) [57]. These bioassessment tools were designed to be robust and have applicability for detecting stream degradation across a wide range of stressors [58] [59] and across gradients in land use [60] [61], ecoregions [62], or individual watersheds [63]. However, there is some indication that typical multimetric assessment approaches for evaluating the health and impairment status of wadeable streams may not be as sensitive or appropriate when applied to urban waterways, because stressor responses of several metrics have not been fully characterized in these environments. To improve the ability of this assessment approach, several papers have alluded to the a priori metric selection process as an important step in assembling a multimetric index that meets certain goals or criteria [57] [64]. Literature suggests that this approach in metric selection is necessary to achieve an index that not only correlates well with measures of degradation causes, but also is important for reducing redundancy among metric components [56] [65]. Several screening or filtering steps applied to the data have been suggested as a process for selecting metrics, including correlations between environmental variables [18] [38], regressions [66] [67], empirical methods associated with water quality [44] [65], and conformation with environmental gradients measured across multiple sites or spatial scales [61] [68]. However, we are unaware of any literature that has utilized local-scale metric responses to predict changes in biotic condition in urban waterways receiving a significant point source of nutrients.

In 2007, the Blue River Main WWTF in Johnson County, Kansas upgraded to increase capacity and implement biological nutrient removal. The U.S. Geological Survey (USGS), in cooperation with Johnson County Wastewater, conducted a study to evaluate the effects of post-expansion wastewater discharges on the upper Blue River. Data were collected to allow assessment of chemical and ecological characteristics upstream and downstream of the discharge. Assessments included stream habitat, periphyton and macroinvertebrate communities, stream metabolism, and water quality parameters to define average and total annual concentrations and loads of nutrients. This paper reports the specific results of the macroinvertebrate portion of the assessment, and documents metric responses and simple predictive models that can be utilized for evaluating other urban streams in the Kansas City metropolitan area. This study can be used to help achieve permit requirements and has implications on land use planning, best management practices (BMP's), and wastewater and stormwater management in urban areas. Specifically, the objectives of this portion of the overall study were to: 1) examine responses of macroinvertebrate indicator metrics to the wastewater discharge with statistical comparisons between sites upstream and downstream of the discharge, 2) identify the best macroinvertebrate indicator metrics for detecting these site differences, and 3) determine combinations of metrics that can be used to predict changes in stream quality within the reach. Pre-expansion water-quality and biological data collected by USGS from the Blue River watershed were used to supplement analyses and interpretation. The approach and results from this study provide a useful tool for evaluating the health of urban stream systems and monitoring trends in area streams that receive wastewater discharges. Most of the data and results from the overall study are reported in [69] and available at http://pubs.usgs.gov/sir/2010/5248/pdf/sir2010-5248.pdf.

\section{Description of Study Area}

Johnson County is the fastest growing county in Kansas, and with a current human population of 534,093 is part of the greater Kansas City metropolitan statistical area in Kansas and Missouri [70]. In Johnson County, both small and large capacity WWTF's often discharge treated wastewater into small streams rather than into larger receiving systems nearby such as the Kansas or Missouri Rivers. The county has 14 facilities that meet this description [71]. This study was conducted in the Blue River watershed $\left(725 \mathrm{~km}^{2}\right)$ which includes portions of Johnson and Wyandotte Counties in Kansas and Jackson and Cass Counties in Missouri. The headwaters are located in Johnson County, Kansas and the stream flows northeast into the Missouri River. Land use in headwaters 
is predominantly rural; however, urban land use increases in the downstream direction as the river flows through the Kansas City metropolitan area (Figure 1). The Blue River Main wastewater treatment facility (WWTF) discharges treated wastewater effluent (point source) into the Upper Blue River via Negro Creek in Johnson County, Kansas (hereafter referred to as "discharge"). The WWTF underwent upgrades during 2005-2007 to increase capacity and implement biological nutrient removal. This facility is currently the second largest of three WWTF's in the watershed and contributes about 25 percent of the total effluent based on 2007 and 2008 data [72] [73]. Expansion and upgrades increased average daily design flow from 3 million gallons per day (mgd) to 10.5 mgd and extended aeration activated sludge was replaced with a biological nutrient removal activated sludge system. The implemented biological nutrient removal is a modification of traditional biological treatment processes that enhances the removal of nitrogen and phosphorus [74]. To ensure protection of water quality and aquatic life, the National Pollutant Discharge Elimination System (NPDES) permit for the expansion and upgrades to the Blue River WWTF requires an evaluation of effluent impacts on the receiving stream after upgrades are complete (Kansas NPDES permit number M-MO26-0006).

State agencies in Kansas and Missouri have listed several Johnson County and Jackson County streams as impaired waterways under section 303(d) of the Clean Water Act [75] [76]. Kansas lists two impaired uses for the upper Blue River in Johnson County, upstream of the WWTF discharge: dissolved oxygen is listed as an impairment of aquatic life and mercury is listed as an impairment of food procurement [77]. In Jackson County Missouri, the Blue River is not listed as impaired within the study reach [76], however previous studies indicate that water quality in the lower portion of this reach is moderately to severely degraded [41] [78].

To characterize water-quality and biological community response to the WWTF discharge, we sampled three sites along a 10.2 kilometer segment of the Blue River (Figure 1): Kenneth Road (site 1) in Johnson County, Kansas (approximately 3.2 kilometers upstream of the WWTF discharge location and hereafter referred to as the "upstream site"); $151^{\text {st }}$ Street (site 2) in Jackson County, Missouri (approximately 0.4 kilometers downstream of the WWTF discharge location, and hereafter referred to as one of the "downstream sites"); and Blue Ridge Boulevard (site 3) in Jackson County, Missouri (approximately 6.6 kilometers downstream of the WWTF discharge location and hereafter referred to as the "furthest downstream site"). Within the study reach, urban land use increases from about $20.7 \%$ at site 1 to $25.8 \%$ percent at site 3 , and impervious surface area increases from about $5.8 \%$ to $7.7 \%$ [69]. The overall study included discrete and continuous water quality monitoring, seasonal sampling of algae and macroinvertebrate communities, determination of stream metabolism, and a stream habitat assessment. This paper reports the results of the macroinvertebrate community assessment, and the remaining data on other parameters can be found in [69].

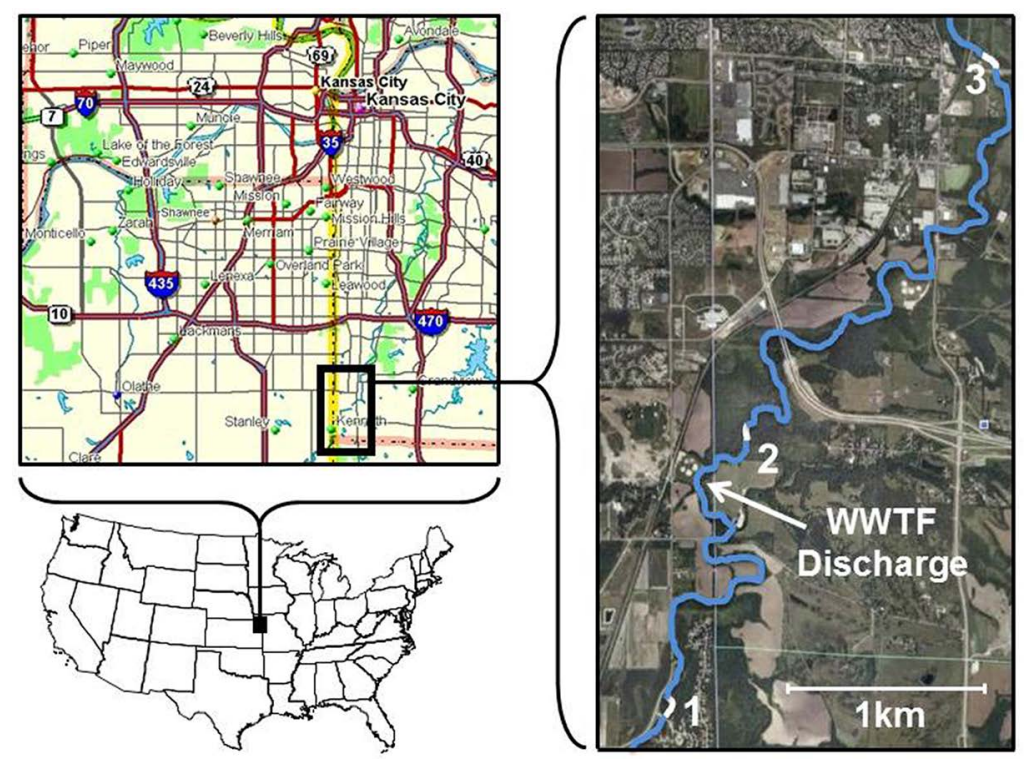

Figure 1. Location of upper Blue River study sites sampled for macroinvertebrate communities in 2008 during spring and late summer time periods. Site $1=$ Kenneth Road; Site $2=151^{\text {st }}$ Street; Site 3 = Blue Ridge Boulevard. 


\section{Previous Investigations}

Blue River sites 1 and 3 have been included in several water quality studies of Johnson County streams or largescale assessments within the watershed [40] [41] [71] [78]-[80]. Continuous streamflow and water-quality data have been collected at two sites upstream of the discharge location (including our site 1) since 2004 and streamflow data have been collected at site 3 since 2001. These studies have indicated that during low-flow conditions (<than base flow), effluent from WWTF discharges may represent more than 99 percent of streamflow [40] [41] [78] [80]. During base-flow conditions, concentrations of nutrients, dissolved solids, pharmaceuticals, and organic wastewater compounds are higher at sites downstream from the WWTF dischargeas compared to sites upstream. Because of the diluting effect of wastewater, sediment and bacteria concentrations and turbidity are typically lower downstream from these discharge locations [40] [41] [78] [80]. Reference [41] [78] found that in the Upper Blue River watershed, more than $70 \%$ of the total nitrogen and phosphorus loads and a majority of sediment, bacterial, and biochemical oxygen demand loads, were contributed by nonpoint sources during precipitation runoff events (hereafter referred to as “stormwater"). At base flow, the Blue River Main WWTF contributes about 28 percent and 16 percent to total nitrogen and phosphorus loads, respectively [41] [78] [80]. Reference [78] also used toxicity test data to determine that diminished aquatic organism health through exposure to contaminants is likely due to chronic long-term exposure, rather than short-term acute toxicity.

Biotic condition assessments using macroinvertebrates have been regularly conducted in the Blue River watershed since 2002 [41] [78] and in Johnson County streams since 2003 [71] [79] [80]. Assessments of habitat quality, algae and periphyton communities have also been previously conducted at upper Blue River sites, including site 1 and 3 in this study [69] [79] [80]. Sites in the upper Blue River watershed upstream of the WWTF discharge have consistently attained among the highest in habitat quality assessment scores within the Blue River watershed and Johnson County, Kansas [78] [80], indicating that on a regional scale, habitats at these sites are least impacted by human activities. However, habitat scores decline in the downstream direction as the watershed becomes increasingly urban. Sites in Johnson County Kansas that are most highly influenced by urbanization factors consistently score the lowest in macroinvertebrate biotic condition scores, while sites that are located in more rural areas, including Blue River sites upstream of WWTF discharge, consistently have among the highest macroinvertebrate biotic condition scores [71] [79] [80]. At site 3 downstream from the Blue River Main WWTF discharge, biotic condition scores are typically lower than sites located upstream of the WWTF; however, scores at this site are higher than at sites located further downstream in the increasingly urban portions of the watershed.

Between site 1 and 3, an increase in nitrogen heterotrophic diatoms and algae taxa associated with eutrophication has been documented [69]. This study also confirmed that within our study reach, ecoregion-based nutrient criteria are always exceeded. Among Johnson County stream sites, chlorophyll concentrations exceeded the nuisance threshold of $100 \mathrm{mg} / \mathrm{m}^{2}$ at about half of the sites studied, including site 1 in the present study [80]. However, stream metabolism in the present study reach is known to be impaired only in the summer months during low flow conditions [69]. Overall, previous biological studies indicate that biological condition of streams is related to several urbanization factors including percent urban land use, percent impervious cover, and organic enrichment resulting from a combination of wastewater discharges and non-point source runoff. Current and historical streamflow and continuous water-quality data are available online at:

http://waterdata.usgs.gov/nwis.

\section{Materials and Methods}

\subsection{Macroinvertebrate Sample Collection}

Macroinvertebrate community samples were collected from multiple habitats at the three sites (Figure 1) during base flow conditions on April 1-2 and Aug. 26-28, 2008. All samples were collected in triplicate to allow determination of statistical differences in biological communities between sites. No runoff events occurred during the 10-day period prior to sample collection. Macroinvertebrates were sampled using a $23 \mathrm{~cm} \times 46 \mathrm{~cm}$ rectangular-frame kicknet (500 $\mu \mathrm{m}$ mesh) and the KDHE protocol designed for evaluating aquatic life status of Kansas streams [81]. This protocol is a "rapid” assessment method designed to quickly inventory macroinvertebrates in a systematic fashion to generate estimates of taxonomic richness and relative abundances at a site [81]. The protocol includes timed, systematic sampling from multiple habitat types to generate one pooled 200-organism 
sample. Two independent 100-organism samples were collected simultaneously from multiple habitats by two scientists for no more than one hour each. If 100 organisms were not obtained by each collection in the allotted time period, sampling ended. Riffle habitats were sampled by physical disturbance of the substrate upstream from the net, and in pool and shoreline habitats, the net was used with a sweeping or scooping motion. These habitats included coarse gravel and cobble in riffles, fine gravel and sand/silt substrates near stream margins or in runs, leaf packs in riffles and organic matter accumulations in pools, vegetation and undercut banks around snags and pool margins, and large moveable objects such as logs or rocks where handpicking may reveal additional taxa. A white sorting tray (31 in. $\times 25$ in. $\times 2.75$ in.) elevated on a portable stand at streamside filled with a small amount of water was used to enhance the visibility of the organisms during sorting and organism removal. With the aid of a hand counter and forceps, organisms were removed (picked) from each individual net sample placed into the tray, then placed in sample bottles containing ethanol preservative. To improve consistency between sample collections and minimize sorting bias, the following stipulations were applied to the protocol: 1) net samples were taken across a relatively uniform coverage of the habitats available at the site, 2) any organisms appearing different in size, shape or color compared to those previously picked from the tray were included in the sample in an attempt to maximize taxonomic richness, 3) multiple individuals of commonly encountered taxa were picked from each successively sorted tray sample to assure that samples adequately represented the frequency of occurrence (and approximate relative abundance) of each taxon at the site, and 4) not more than 25 percent of the organisms sorted and removed came from any one of the available habitats. To enhance statistical comparisons among sites, the same sampling protocol was applied three successive times (one at each of three separate riffle-pool sequences) within the study reach at each site, beginning with the most downstream and working upstream. For each replicate, data from both independently collected 100-organism samples were pooled before analysis to minimize differences in sorting bias between the two scientists performing the collections, as indicated in the Kansas Protocol [81]. All of the 100-organism samples were field preserved in $125 \mathrm{ml}$ wide mouth polyethylene bottles containing $80 \%$ ethanol. Identification and enumeration of macroinvertebrate samples were performed by the USGS National Water Quality Laboratory (NWQL) in Lakewood, Colorado. Each macroinvertebrate specimen was identified to the lowest possible taxonomic unit, usually genus or species, using all available keys and literature. Standard taxonomic references used for macroinvertebrate identification include [82] for insects, and [83] for non-insect macroinvertebrates. Other references used for specific taxonomic groups are given in reference [84] [85]. Macroinvertebrate samples and laboratory-prepared slides were processed, identified and enumerated within one year from the date of collection. Quality assurance and quality control measures for macroinvertebrate identification, enumeration and data entry followed those outlined in [84].

\subsection{Calculation of Metrics}

Thirty four metrics were initially chosen to represent the macroinvertebrate data. These included core metrics used in Kansas and Missouri for determining aquatic life impairment status of streams [75] [76], those used for multimetric site scoring in [79] and [71] [80], and an additional 23 metrics selected from the Rapid Bioassessement Protocols [86]. We chose metrics known to be sensitive and reliable for measuring stream degradation or impairment status, and those that would allow comparisons with data from previous Blue River studies. Metric values were generated by the Invertebrate Data Analysis System (IDAS) developed for the National Water Quality Assessment Program [87], or in cases where a metric was not included in this program, were calculated directly from the data as described in [86] or [79]. Metrics were placed into one of six categories based on [79] and available literature (Table 1 ).

\subsection{Site Scoring}

Community data were used to generate site scores that represent an integrated numerical rating of relative biotic condition. Two different types of scores were generated for this study: 1) aquatic life scores based on a point system and KDHE criteria [75], and 2) a biotic condition attainment score based on the 10 metrics used to evaluate regional streams during previous studies that included sites within the Blue River watershed [71] [79] [80]. The aquatic life score was used to determine impairment status of the study sites, and was determined by an average of individual metric scores across the four KDHE metrics. A fifth metric, percent mussel community loss, was not used in this score because we were unable to determine if our sites met the criteria of having at least five 
Table 1. Macroinvertebrate metrics calculated for assessment of biological condition in the upper Blue River, Kansas and Missouri, April and September 2008. Use: 1 = utilized in previously published bioassessments conducted in the region; $2=$ from Rapid Bioassessment Protocols; 3 = core metric in state bioassessment programs in KS and/or MO.

\begin{tabular}{|c|c|c|c|c|}
\hline Metric & Abbreviation & Metric Category & Use & $\begin{array}{c}\text { Response to } \\
\text { Stress }\end{array}$ \\
\hline Chironomidae richness & Chir $_{\text {rich }}$ & Richness & 2 & Decrease \\
\hline Diptera richness & Dipt ${ }_{\text {rich }}$ & Richness & 2 & Decrease \\
\hline Ephemeroptera richness & $\mathrm{Eph}_{\text {rich }}$ & Richness & 2 & Decrease \\
\hline Ephemeroptera + Plecoptera + Trichoptera richness & $\mathrm{EPT}_{\text {rich }}$ & Richness & $1,2,3$ & Decrease \\
\hline Plecoptera richness & Plec $_{\text {rich }}$ & Richness & 2 & Decrease \\
\hline Total taxa richness & $\mathrm{TT}_{\text {rich }}$ & Richness & $1,2,3$ & Decrease \\
\hline Trichoptera richness & Tric $_{\text {rich }}$ & Richness & 2 & Decrease \\
\hline \% Chironomidae & Chir $_{\mathrm{cp}}$ & ${ }^{\mathrm{b}}$ Composition/\% & 2 & Increase \\
\hline$\%$ Corbicula & Corb $_{\text {cp }}$ & ${ }^{\mathrm{b}}$ Composition/\% & 2 & Increase \\
\hline \% Diptera & $\operatorname{Dipt}_{\mathrm{cp}}$ & ${ }^{\mathrm{b}}$ Composition/\% & 2 & Increase \\
\hline \% Ephemeroptera & $\mathrm{Eph}_{\mathrm{cp}}$ & ${ }^{\mathrm{b}}$ Composition/\% & 2 & Decrease \\
\hline \% Ephemeroptera + Plecoptera & $\mathrm{EP}_{\mathrm{cp}}$ & ${ }^{\mathrm{b}}$ Composition/\% & 1 & Decrease \\
\hline \% Ephemeroptera + Plecoptera + Trichoptera & $\mathrm{EPT}_{\mathrm{cp}}$ & ${ }^{\mathrm{b}}$ Composition/\% & $1,2,3$ & Decrease \\
\hline \% Hydropsychidae Trichoptera & $\operatorname{HydT}_{\mathrm{cp}}$ & ${ }^{\mathrm{b}}$ Composition/\% & 2 & Increase \\
\hline$\%$ Other Diptera + Non-insects $^{\mathrm{a}}$ & $\mathrm{ODNI}_{\mathrm{cp}}$ & ${ }^{\mathrm{b}}$ Composition/\% & 2 & Increase \\
\hline \% Oligochaeta & Oligo $_{\mathrm{cp}}$ & ${ }^{\mathrm{b}}$ Composition/\% & 1,2 & Increase \\
\hline$\%$ Plecoptera & Plec $_{\mathrm{cp}}$ & ${ }^{\mathrm{b}}$ Composition/\% & 2 & Decrease \\
\hline \% Tanytarsini midges & Tany $_{\mathrm{cp}}$ & ${ }^{\mathrm{b}}$ Composition/\% & 1,2 & Decrease \\
\hline$\%$ Trichoptera & Tric $_{\mathrm{cp}}$ & ${ }^{\mathrm{b}}$ Composition/\% & 2 & Decrease \\
\hline Clinger richness & ClingR $_{\mathrm{fh}}$ & Functional/Habitat & 2 & Decrease \\
\hline \% Clingers & ClingP $_{\text {fh }}$ & Functional/Habitat & 2 & Decrease \\
\hline$\%$ Filterers & Filt $_{\mathrm{fh}}$ & Functional/Habitat & 2 & Increase \\
\hline$\%$ Predators & Pred $_{\mathrm{fh}}$ & Functional/Habitat & 2 & Increase \\
\hline$\%$ Scrapers & $\mathrm{Sc}_{\mathrm{fh}}$ & Functional/Habitat & 1,2 & Decrease \\
\hline \% Shredders & $\mathrm{Sh}_{\mathrm{fh}}$ & Functional/Habitat & 2 & Decrease \\
\hline \% Intolerant taxa $(\mathrm{KBI}$ tolerance $<3.0)$ & IntKBI ${ }_{\text {tol }}$ & Tolerance & 1,2 & Decrease \\
\hline Kansas Biotic Index & $\mathrm{KBI}_{\text {tol }}$ & Tolerance & 1,3 & Increase \\
\hline Macroinvertebrate Biotic Index & $\mathrm{MBI}_{\text {tol }}$ & Tolerance & 1,3 & Increase \\
\hline \% Dominant taxon & $\mathrm{DT} 1_{\mathrm{dd}}$ & Dominance/Diversity & 2 & Increase \\
\hline$\%$ of 2 dominant taxa & $\mathrm{DT} 2_{\mathrm{dd}}$ & Dominance/Diversity & 2 & Increase \\
\hline$\%$ of 5 dominant taxa & $\mathrm{DT5}_{\mathrm{dd}}$ & Dominance/Diversity & 2 & Increase \\
\hline Shannon Diversity Index & $\mathrm{SDI}_{\mathrm{dd}}$ & Dominance/Diversity & 1,3 & Decrease \\
\hline EPT/Chironomidae ratio & EPTC $_{\text {ratio }}$ & Ratio & 2 & Decrease \\
\hline Scraper/Filtering collector ratio & $\mathrm{ScFc}_{\text {ratio }}$ & Ratio & 2 & Decrease \\
\hline
\end{tabular}

${ }^{\mathrm{a}}$ Excludes Chironomidae; ${ }^{\mathrm{b}}$ Percent (\%) relative abundance. 
mussel species [75]. The biotic condition score (hereafter defined as biotic condition attainment score) was calculated for each replicate sample by implementing the "percent (\%) of best value" approach commonly used by previous biological assessment research studies [62] [88]-[90]. Metric data from all stream sites in the Blue River watershed that have been previously sampled with the KDHE protocol since 2003 [71] [79] [80] were examined to identify the best values attained among these sites for each metric (best value $=$ the highest observed value available for metrics that decrease with increasing perturbations, and the lowest observed value for metrics that increase with increasing perturbations). These metric values were compared with metric values from sample data generated by the current study to calculate individual percentages of these best metric values. Mean percent attainment was determined by a summation of individual percentages for each of the 10 metrics to obtain an overall site score that represented relative stream quality for each sample replicate. This attainment score represents the degree of attainment for each site and can either be expressed as a non-weighted average (mean) across all 10 metrics (\%) or a summation of percentages, the only difference being location of the decimal (i.e. score of $849=84.9 \%$ average attainment). This biotic condition attainment score was utilized for relative site comparisons, further statistical analyses, and was treated as the response (dependent) variable for metric selection and assemblage of regression models.

\subsection{Data Analysis}

All analyses were conducted using release 9.2 of the Statistical Analysis System for Windows [91]. Analyses were performed independently for the April and August 2008 sampling periods. A non-parametric analysis of variance (ANOVA) was used to test for statistical differences among sites (p-value $<0.05$ ) for individual metrics and the biotic condition attainment score. Since ANOVA does not identify which means are significantly different when more than two means are involved, we used least-squares means $(\alpha=0.05)$ and simultaneous confidence intervals to make pairwise comparisons among site means to determine which were significantly different [92]. To select the best metrics for detecting site differences and develop models for predicting the percent attainment score of a site, data were entered into a stepwise multiple regression procedure (PROC REG, selection = STEPWISE) and included all interaction variables. This procedure was performed with two separate steps: 1) STEPWISE generated a list of the best metrics for detecting site differences (i.e. metrics that add significantly to the predicted outcome), with a model entrance criteria of $p=0.15$, and 2 ) the REG procedure generated models that represent those statistically significant combinations of metrics that would accurately predict the percent attainment score of a site. Since our analyses included all 34 metrics as independent variables, the multiple regression procedure was expected to generate a large number of significant models, and in many cases include metrics which are redundant or correlated with one another. Therefore, we screened the results so that the selected "best" models not only had the highest $\mathrm{R}^{2}$, but also fit the following criteria: 1 ) only models including three, four, and five metrics with no interaction terms were considered, 2) included metrics must be either those with statistical ANOVA significance among sites for at least one time period, chosen by the STEPWISE procedure, or found in at least $50 \%$ of the models that had significant $R^{2}$ values, and 3 ) only one metric is included from each metric category listed in Table 1 to reduce the degree of redundancy among model components. We assumed that if a model included no more than one metric within a category, then those models would be least likely to include metrics which would be redundant or correlated with one another.

\section{Results}

\subsection{Changes in Composition and Dominance}

In this study, 210 macroinvertebrate taxa were collected across the three Blue River sites in 2008, 31 of which were non-insect taxa (mostly mollusks, worms, leeches, and crustaceans). Also, 124 of these taxa were collected during the April 2008 sampling and 111 taxa were collected during the Aug. 2008 sampling. Total richness of macroinvertebrate taxa within a sample replicate ranged from 36 - 54 across sites. Among the 179 insect taxa, 37 of these were among the three dominant orders of insects that are normally associated with healthy stream communities (Ephemeroptera, mayflies; Plecoptera, stoneflies; and Trichoptera, caddisflies). The number of EPT taxa ranged from 6 to 14 across samples and sampling periods, and EPT abundances in samples ranged from 23.7\% - 33.8\% in April and 8.4\% - 15.7\% in August. There were also 45 midge (Diptera: Chironomidae) taxa, and 8 non-midge Diptera taxa. In addition to these, our Blue River study sites generally contained a wide 
diversity of other aquatic macroinvertebrates, including dragonflies and damselflies (Odonata), riffle beetles (Coleoptera: Elmidae) and aquatic heteropterans (Hemiptera).

Differences in the most dominant taxa among sites (based on mean abundance estimates for the three sample replicates) were more pronounced during the April sampling period. The mayfly Stenonema femoratum (Ephemeroptera: Heptageniidae) was among the five most dominant macroinvertebrates at all of the sites in April. Midges in the Cricotopus/Orthocladius species complexes were also among the five most dominant taxa in April at all three sites, and relative abundance increased downstream of the WWTF discharge. Also in April, the mayfly Acerpenna pygmaea was among the five most dominant taxa at the upstream site but was absent at site 3 . The riffle beetle Stenelmis spp. was among the five most dominant taxa at two of the three sites in April and all three sites during August. The caddisfly Cheumatopsyche spp. was among the five most dominant taxa at the furthest downstream site (site 3) in April, and at all three sites in August. The midge Polypedilum spp. was also among the five most dominant at all three sites in August. Also in August, the damselfly Enallagma spp. was among the five most dominant taxa at the two upstream sites, and the mayfly Baetis spp. was among the five most dominant taxa at the two sites downstream of the WWTF discharge.

In April, tolerant net-spinning caddisflies (Hydropsychidae) and the mayfly Tricorythodes were more abundant at downstream sites, and the more sensitive Plecoptera (five species) and the caddisfly Rhyacophila lobifera (Trichoptera: Rhyacophilidae) were less abundant at site 2 and absent at site 3. In August, four caddisflies (Trichoptera) present at site 1 were absent at both downstream sites. Four mayflies and the hellgrammite Corydalus (Megaloptera: Corydalidae) were present at the upper two sites, but were absent at site 3 . Total mayflies in the family Heptageniidae were less abundant below the WWTF effluent, whereas two of the midge (Chironomidae) taxa (Dicrotendipes and Cricotopus/Orthocladius) increased [69]. In all, 13 EPT taxa (4 mayflies, 5 stoneflies, and 4 caddisflies) present at site 1 were absent at one or both sites downstream of the effluent discharge location.

\subsection{Metric Responses}

Values for metrics in which significant differences were detected among sites are given in Table 2, and include 15 metrics in April and 12 metrics in August. A total of 12 metrics did not show significant differences between sites in either sampling period. Significant differences existed among sites during both sampling periods for five metrics, including $\mathrm{EPT}_{\mathrm{cp}}, \mathrm{ScFC}_{\text {ratio, }} \mathrm{IntKBI}_{\mathrm{tol}}, \mathrm{EPTC}_{\text {ratio }}$ and $\mathrm{Corb}_{\mathrm{cp}}$ (Table 2). At site 1, EPT richness $\left(\mathrm{EPT}_{\text {rich, }}\right.$, all $\mathrm{p} \leq 0.01)$, percent shredders $\left(\mathrm{Sh}_{\mathrm{cp}}, \mathrm{p} \leq 0.02\right)$ and the relative abundance and richness of stoneflies $\left(\mathrm{Plec}_{\mathrm{cp}}\right.$ and

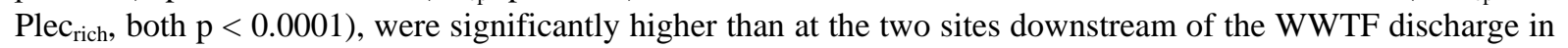
April. Data from the April sampling period also showed that site 1 had significantly lower values than the two downstream sites for two of the dominant taxa metrics (DT1 $1_{d d}, p \leq 0.01$; $D T 2_{d d}, p \leq 0.01$ ), percent of caddisflies that were Hydropsychidae ( $\mathrm{HydT}_{\mathrm{cp}}, \mathrm{p} \leq 0.01$ ), and the Kansas Biotic Index $\left(\mathrm{KBI}_{\mathrm{tol}}, \mathrm{p} \leq 0.01\right)$. Similarly, percent scrapers $\left(\mathrm{S}_{\mathrm{fh}}, \mathrm{p}=0.004\right)$ and the scraper/filterer ratio $\left(\mathrm{ScFF}_{\text {ratio, }}, \mathrm{p}=0.02\right)$ had significantly higher values at site 1 as compared to the two sites downstream of the WWTF discharge location in August (Table 2).

\subsection{KDHE Aquatic Life Support Scores}

The KDHE integrates responses of four metrics to determine the impairment status and ability of a stream site to support aquatic life: $\mathrm{MBI}_{\mathrm{tol}}, \mathrm{KBI}_{\mathrm{to}}, \mathrm{EPT}_{\text {rich }}$, and $\mathrm{EPT}_{\mathrm{cp}}$ [81]. Only site 1 attained a fully supporting rating for any of the four metrics, and these were $\mathrm{KBI}_{\text {tol }}$ in April and $\mathrm{EPT}_{\text {rich }}$ during both sample periods. All three sites were rated non-supporting for the $\mathrm{EPT}_{\mathrm{cp}}$ metric during the August sampling period. Among sample replicates, the KDHE multimetric score based on these four metrics ranged from 1.6 to 2.4 in April and 1.3 to 1.9 in August. In April, all three sites attained a partially supporting aquatic life status, although scores at the two downstream sites (site 2 and 3) were significantly lower $(\mathrm{p}<0.01)$ than the score at the upstream site (site 1$)$. Scores at all sites were lower in August than in April; however the upstream site and furthest downstream site (site 3) attained a partially supporting aquatic life status, while the site immediately downstream of the wastewater discharge (site 2) was non-supporting. Results for the upstream site (site 1) were similar to that from previous studies, where a partially-supporting status was reported in both 2003 and 2004 [79] and again in 2007 [80]. In contrast, the most downstream site (site 3) was reported as partially-supporting in 2003 and non-supporting in 2004 [79]. However, previous studies have indicated that biological condition of upper Blue River sites in Kansas (including site 1 in this study) are generally among the least impacted by human disturbance as compared to 
Table 2. Macroinvertebrate metric analysis results ( $p$ values in parentheses) for assessment of biological condition in the upper Blue River, Kansas and Missouri, April and August, 2008. Metric abbreviations are defined in Table 1. Site numbers are as follows: $\mathbf{1}=$ Kenneth Road, $2=151^{\text {st }}$ Street, $\mathbf{3}=$ Blue Ridge Boulevard. NS = not significant.

\begin{tabular}{|c|c|c|c|c|}
\hline Metric & $\begin{array}{c}\text { April } 2008 \\
\text { ANOVA Significance }\end{array}$ & $\begin{array}{c}\text { August } 2008 \\
\text { ANOVA Significance }\end{array}$ & Chosen by Stepwise & Included in Models \\
\hline Chir $r_{\text {rich }}$ & NS & NS & $\mathrm{X}$ & \\
\hline Dipt $_{\text {rich }}$ & NS & NS & & \\
\hline $\mathrm{Eph}_{\text {rich }}$ & NS & NS & & \\
\hline $\mathrm{EPT}_{\text {rich }}$ & $1>2=3(0.017)$ & NS & & $\mathrm{X}$ \\
\hline Plec $_{\text {rich }}$ & $1>2=3(0.003)$ & NS & & $\mathrm{X}$ \\
\hline $\mathrm{TT}_{\text {rich }}$ & NS & NS & $\mathrm{X}$ & \\
\hline Tric $_{\text {rich }}$ & NS & $1>2=3(0.035)$ & $\mathrm{X}$ & $\mathrm{X}$ \\
\hline Chir $_{\mathrm{cp}}$ & NS & NS & & \\
\hline $\operatorname{Corb}_{\mathrm{cp}}$ & $1<2=3(0.007)$ & $1<2<3(0.008)$ & & \\
\hline $\operatorname{Dipt}_{\mathrm{cp}}$ & NS & NS & & \\
\hline $\mathrm{Eph}_{\mathrm{cp}}$ & NS & $1=2>3(0.018)$ & & \\
\hline $\mathrm{EP}_{\mathrm{cp}}$ & NS & $1=2>3(0.018)$ & & \\
\hline $\mathrm{EPT}_{\mathrm{cp}}$ & $1>3$ only $(0.046)$ & $1=2>3(0.0003)$ & $\mathrm{X}$ & $\mathrm{X}$ \\
\hline HydT $_{\text {сp }}$ & $1<2=3(0.001)$ & NS & & \\
\hline $\mathrm{ODNI}_{\mathrm{cp}}$ & NS & $1<2=3(0.018)$ & $\mathrm{X}$ & $\mathrm{X}$ \\
\hline Oligo $_{\mathrm{cp}}$ & NS & $2<1=3(0.046)$ & $\mathrm{X}$ & \\
\hline Plec $_{\mathrm{cp}}$ & $1>2=3(0.005)$ & NS & $\mathrm{X}$ & \\
\hline Tany $_{\mathrm{cp}}$ & NS & NS & & $\mathrm{X}$ \\
\hline Tric $_{\mathrm{cp}}$ & $1=2>3(0.003)$ & NS & $\mathrm{X}$ & \\
\hline ClingR $_{\text {fh }}$ & NS & NS & $\mathrm{X}$ & $\mathrm{X}$ \\
\hline ClingP $_{\text {fh }}$ & NS & NS & & \\
\hline Filt $_{\mathrm{fh}}$ & $2>1=3(0.002)$ & NS & & $\mathrm{X}$ \\
\hline Pred $_{f h}$ & NS & NS & & \\
\hline $\mathrm{Sc}_{\mathrm{fh}}$ & NS & $1>2=3(0.010)$ & $\mathrm{X}$ & \\
\hline $\mathrm{Sh}_{\mathrm{fh}}$ & $1>2=3(0.030)$ & NS & & \\
\hline IntKBI $_{\text {tol }}$ & $1>2=3(0.002)$ & $1>2=3(0.019)$ & & \\
\hline $\mathrm{KBI}_{\text {tol }}$ & $1<2<3(<0.0001)$ & NS & $\mathrm{X}$ & $\mathrm{X}$ \\
\hline $\mathrm{MBI}_{\text {tol }}$ & NS & $1<3$ only $(0.013)$ & $\mathrm{X}$ & $\mathrm{X}$ \\
\hline $\mathrm{DT} 1_{\mathrm{dd}}$ & $1<2<3(0.004)$ & NS & & $\mathrm{X}$ \\
\hline $\mathrm{DT} 2_{\mathrm{dd}}$ & $1<2=3(0.035)$ & NS & & $\mathrm{X}$ \\
\hline $\mathrm{DT5}_{\mathrm{dd}}$ & NS & NS & $\mathrm{X}$ & \\
\hline $\mathrm{SDI}_{\mathrm{dd}}$ & NS & NS & & \\
\hline $\mathrm{EPTC}_{\text {ratio }}$ & $1=2>3(0.042)$ & $1>2=3(0.020)$ & & \\
\hline $\mathrm{ScFC}_{\text {ratio }}$ & $2<1=3(0.0008)$ & $1>2=3(0.040)$ & $\mathrm{X}$ & $\mathrm{X}$ \\
\hline
\end{tabular}


other stream sites in Johnson County, Kansas and Jackson County, Missouri [79]. This is further supported by the results from recent 2007 sampling in other streams of Johnson County, Kansas; only one of the 20 stream sites examined in that study had a rating of fully supporting based on the KDHE aquatic life score, and that site (Camp Branch) is located in the upper Blue River watershed [71] [80].

\subsection{Biotic Condition Attainment Scores}

Among all replicates, the biotic condition attainment score ranged from 599 to 865 (mean \% attainment of 59.9 86.5) in April and 669 to 849 (mean \% attainment of 66.9 - 84.9) in August. In April, mean condition at the upstream site (site 1 ) was significantly higher than the two downstream sites $(1>2=3, p=0.03)$. Even though these site differences were not statistically significant during the August sampling period $(p=0.45)$, mean biotic condition scores were higher at the upstream site during this time period (Figure 2).

\subsection{Regression Models}

Considering both April and August time periods, regression analysis generated statistically significant models that included 68 three-variable models, 68 four-variable models, and 64 five-variable models. A total of 27 metrics fit the criteria of either ANOVA significance among sites, chosen by STEPWISE, or were a component of at least $50 \%$ of the significant regression models in one or both time periods (Figure 3). The STEPWISE procedure selected 14 metrics for detecting site differences in the biotic condition attainment score (Table 2). Among these, four were not significantly different across sites based on the ANOVA results for either time period $\left(\mathrm{Chir}_{\text {rich }}, \mathrm{TT}_{\text {rich, }}\right.$, ClingR $\left.\mathrm{R}_{\mathrm{fh}}, \mathrm{DT5}_{\mathrm{dd}}\right)$, and only six of these metrics were included in the best selected regression models (Table 2, Table 3, Figure 3). Among the 13 metrics that were included in at least one of the regression models chosen, only the Tany ${ }_{c p}$ metric did not have ANOVA significance in either time period and was not chosen by the STEPWISE procedure. However, this metric was included in the highest overall percentage of significant models generated by the regression analysis (Figure 3), and was a component of the best 3-metric model in April based on $\mathrm{R}^{2}$ (Table 3). The April metric data generated models with highly significant regression coefficients ( $\mathrm{p}<0.0001$ ), as did the 4- and 5-metric models for August (Table 3). All models included no more than one metric within a metric category. Even though we did not quantify metric redundancy, our goal was to select model components that met certain criteria to reduce redundancy and co-correlation in the suite of metrics

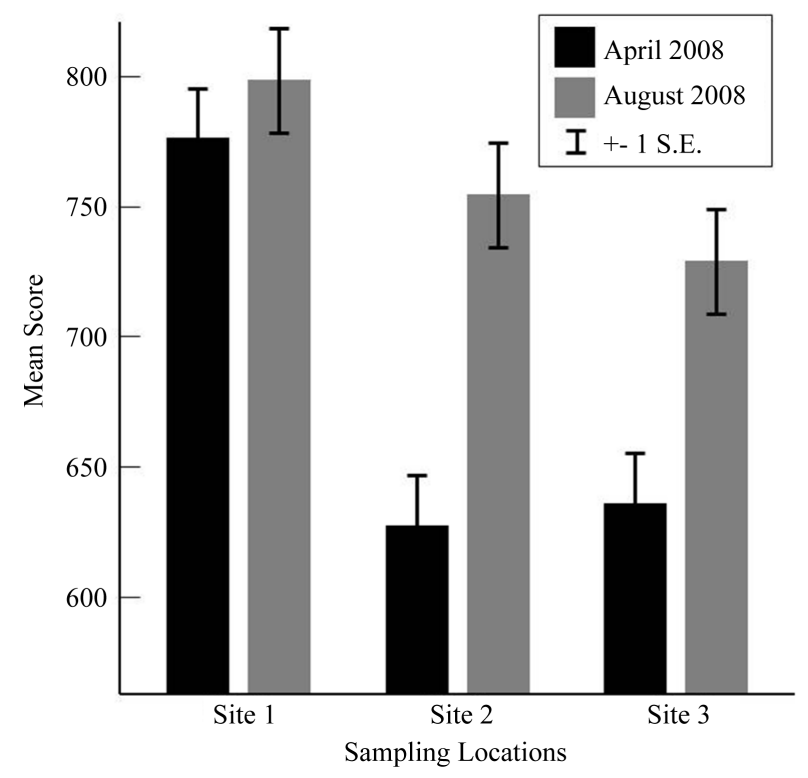

Figure 2. Mean biotic condition scores at three upper Blue River sites sampled during 2 time periods in 2008. Scores were determined by summation of the $\%$ of best attained metric values within the Blue River watershed determined from previous studies [70] [77] [78]. S.E. = standard error. 


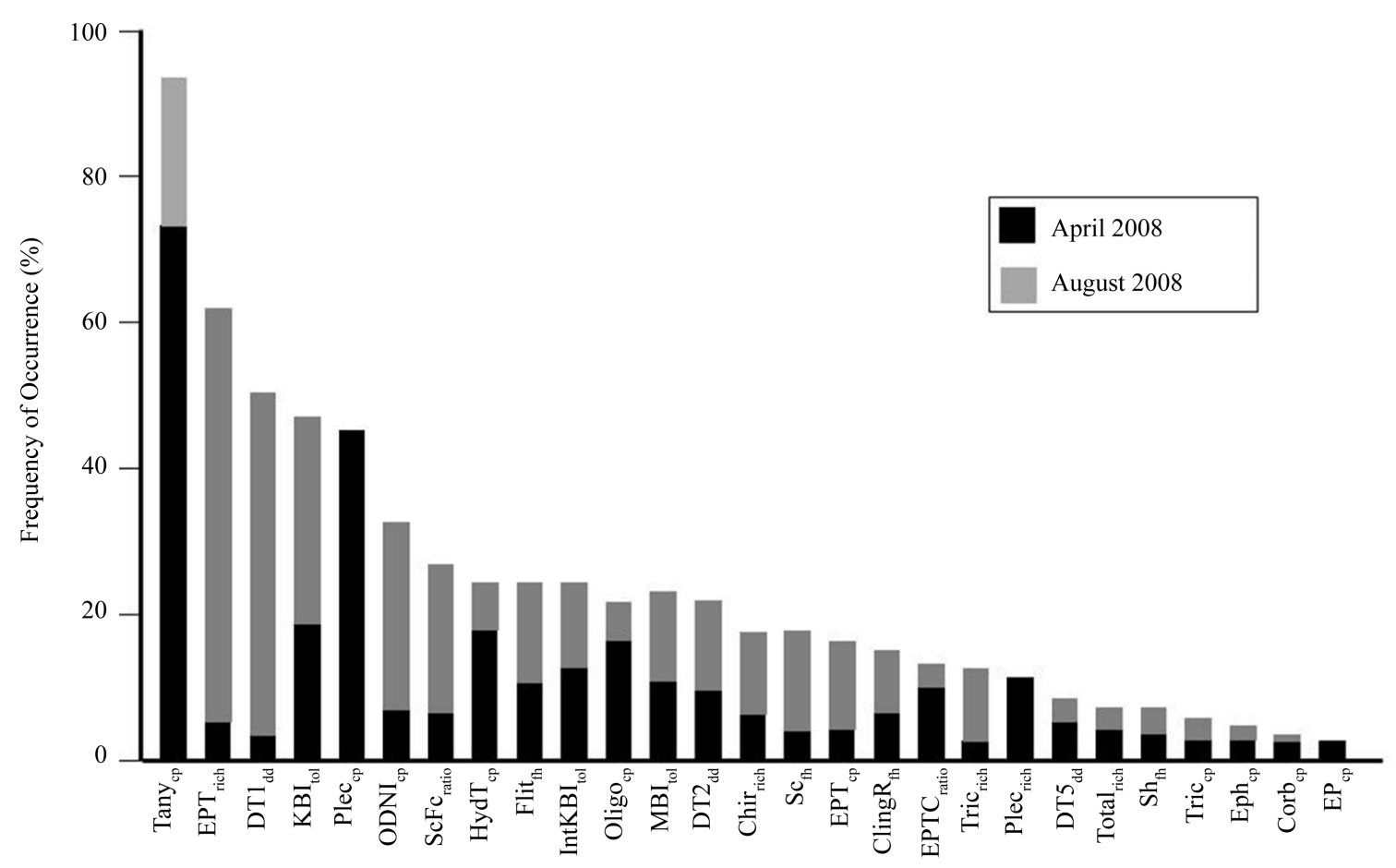

Macroinvertebrate Metric

Figure 3. Frequency (\% occurrence) in which metrics were included in significant multiple regression models used to predict biotic condition score in the upper Blue River sampled in 2008. All 27 metrics were either significantly different among sites (ANOVA) for at least one time period, were chosen by STEPWISE as among the best metrics for predicting biotic condition score (model entrance criteria of $p=0.15$ ), or were included in over $50 \%$ of the significant multiple regression models. Metric abbreviations are defined in Table 1.

Table 3. Metric models and statistics from multiple regression analysis of 34 macroinvertebrate metrics for predicting effects of wastewater discharge on biotic condition in the upper Blue River, for two periods sampled in 2008. Models chosen have the highest $\mathrm{R}^{2}$ among those with the maximum number of metric categories represented (see Table 1). SCORE = summation of percent (\%) attainment.

\begin{tabular}{|c|c|c|c|}
\hline Model Equation & $\begin{array}{l}\text { \# of Metric } \\
\text { Categories }\end{array}$ & ${ }^{\mathrm{a}}$ Model $\mathbf{R}^{2}$ & $\begin{array}{c}\text { ANOVA p } \\
\text { Value }\end{array}$ \\
\hline \multicolumn{4}{|l|}{ April 2008} \\
\hline SCORE $=13613\left(\right.$ Tany $\left._{\mathrm{cp}}\right)+21.51\left(\right.$ Plec $\left._{\text {rich }}\right)-417.4\left(\right.$ Filt $\left._{\mathrm{fh}}\right)+619.9$ & 3 & 0.97 & $<0.0001$ \\
\hline SCORE $=-603.9\left(\mathrm{KBI}_{\mathrm{tol}}\right)-3169\left(\mathrm{Oligo}_{\mathrm{cp}}\right)-62.57\left(\mathrm{Plec}_{\text {rich }}\right)-1811\left(\mathrm{PDT1}_{\mathrm{dd}}\right)+2783$ & 4 & 0.99 & $<0.0001$ \\
\hline $\operatorname{SCORE}=1335\left(\mathrm{KBI}_{\mathrm{tol}}\right)+5809\left(\mathrm{Sc}_{\mathrm{fh}}\right)+22.61\left(\mathrm{Eph}_{\mathrm{rich}}\right)-517.3\left(\mathrm{PDT}_{\mathrm{dd}}\right)-753.6\left(\mathrm{HydT}_{\mathrm{cp}}\right)-2756$ & 5 & 0.99 & $<0.0001$ \\
\hline \multicolumn{4}{|l|}{ August 2008} \\
\hline $\mathrm{SCORE}=298.6\left(\mathrm{ScFc}_{\text {ratio }}\right)+24.36\left(\right.$ Tric $\left._{\text {rich }}\right)+18.54\left(\mathrm{ODNI}_{\mathrm{cp}}\right)+89.72$ & 3 & 0.90 & 0.0019 \\
\hline $\mathrm{SCORE}=-148.6\left(\mathrm{MBI}_{\mathrm{tol}}\right)+32.63\left(\mathrm{EPT}_{\text {rich }}\right)-40.34\left(\mathrm{PDT}_{\mathrm{dd}}\right)+17.77\left(\right.$ Filt $\left._{\mathrm{fh}}\right)+1778$ & 4 & 0.99 & $<0.0001$ \\
\hline $\operatorname{SCORE}=1033\left(\mathrm{KBI}_{\text {tol }}\right)-5.88\left(\mathrm{EPT}_{\mathrm{cp}}\right)+231.2\left(\mathrm{ScFC}_{\text {ratio }}\right)+12.64\left(\right.$ Tric $\left._{\text {rich }}\right)+5.72\left(\mathrm{ClingR}_{\mathrm{fh}}\right)-2376$ & 5 & 0.99 & $<0.0001$ \\
\hline
\end{tabular}

adjusted $\mathrm{R}^{2}$ given from the PROC REG procedure.

included in each of the models. Among the six selected models, richness metrics were represented in all models, composition/\% metrics were represented in all but one model, and both functional/habitat and tolerance categories were represented in four models each (Table 3). In addition, richness metrics included in these models were all associated with EPT insect orders $\left(\mathrm{Eph}_{\text {rich, }} \mathrm{Plec}_{\text {rich }}\right.$, Tric $\mathrm{Crich}_{\text {, }}$ and $\left.\mathrm{EPT}_{\text {rich }}\right)$. Among the six models, the Kansas 
Biotic Index $\left(\mathrm{KBI}_{\mathrm{tol}}\right)$ was a component in 3 models, and five other metrics were a component in two models $\left(\right.$ Plec $_{\text {rich, }}$, Tric $_{\text {rich }}$, Filt $\left._{\mathrm{fh}}, \mathrm{PDT} 2_{\mathrm{dd}}, \mathrm{ScF}_{\mathrm{ratio}}\right)$. Five of the six models chosen also had one metric related to abundance of filtering collectors (Filt $\mathrm{fh}_{\mathrm{fh}}, \mathrm{HydT}_{\mathrm{cp}}$, or $\mathrm{ScFF}_{\mathrm{ratio}}$, Table 3). Considering all metrics that fit the criteria and significant models generated by the regression analysis, the Plecoptera-related metrics Plec $_{\mathrm{cp}}$, Plec $_{\text {rich, }}$ and $\mathrm{EP}_{\mathrm{cp}}$ were exclusive to significant models in April only (Figure 3), and the diversity/dominance and functional/ habitat-related metrics appeared to be more important in predicting biotic condition attainment score during the August time period (Figure 3, Table 3). For this study, our model results would be valid for projecting mean percent attainment only within the range of scores observed for each season (April $=59.9 \%-86.5 \%$; August $=$ $66.9 \%-84.9 \%$ ), and assuming that individual metrics in each of the models are independent indicators of biotic condition.

\section{Discussion}

Features associated with urbanization have caused a variety of ecological impacts to streams and their aquatic communities, and the well- studied Blue River system of the Kansas City metropolitan area is no exception. Urban stream segments containing one clearly defined nutrient point source with the absence of either reach-or watershed-scale changes in habitat or land use upstream, are probably a rare occurrence in most metropolitan areas of the U.S. Our study reach of the upper Blue River fits a more likely scenario where a WWTF discharge is the only distinct point source continuously affecting water quality that differs between study sites. In addition to reporting stream conditions associated with WWTF upgrades, our secondary objectives were to improve our understanding of macroinvertebrate indicator responses resulting from a point-source wastewater discharge, and to identify suites of multiple indicator metrics that can collectively predict changes in stream quality under these conditions. We included responses for additional metrics that may have potential in improving diagnostic capabilities, because screening-level metrics utilized in previous stream quality evaluations can respond to a wide variety of stressors and may alone not be effective at identifying causes of aquatic life impairment.

Our data indicates that macroinvertebrate communities in the Blue River are responding to longitudinal changes in stream conditions. Reference [39] concluded that some impacts on aquatic communities observed in urban streams, including species loss and shifts in dominance to more tolerant taxa, may occur earlier at the beginning of development or at the low end of the urban gradient. Based on macroinvertebrate data from our site 1 and data from two previously studied sites upstream and within the predominantly rural portions of the upper Blue River watershed, this stream reach is known to have among the highest biotic condition of streams in Johnson County, Kansas [71] [79] [80], which suggests that the upper portions of our study reach represents the low end of this urban gradient. This is further evidenced by changes in dominance and composition and the loss of some sensitive EPT taxa at sites downstream of the WWTF discharge. Including both sampling periods, a total of 13 EPT taxa (4 mayflies, 5 stoneflies, and 4 caddisflies) considered intolerant of degraded stream quality were present at the upstream site (site 1) and were absent at one or both of the downstream sites (sites 2, 3). Loss of EPT taxa, shifts in dominance towards more filtering taxa, and a decrease in sensitive taxa, have all been reported in other studies as a response to nutrient increases associated with WWTF discharges in urban areas [34] [93]. The Biological Condition Gradient (BCG) conceptual model also supports the presumption that our study reach represents the lower end of the urban gradient, because loss of sensitive taxa and declines in species richness are among the first biological responses observed when stream degradation is progressing towards greater levels of impairment [94]. Because the BCG model also identifies expected community changes beyond this level of impairment, our study reports responses of other metrics not associated with EPT insect orders, including several of the RBP metrics related to habitat and macroinvertebrate functional feeding groups [86] that have not typically been included in previous urban stream evaluations. Taken together with the reach and landscape scale changes in habitat and land use reported in [69], it appears that our relatively short study reach $(10.7 \mathrm{~km})$ represents the stream segment of the upper Blue River in which rapid and distinct effects on aquatic communities have occurred either in recent past or are presently occurring.

Along our study segment of the Blue River, the concentrations of nutrients we observed increased from upstream to downstream, and were accompanied by a corresponding increase in diatoms associated with nutrient enrichment and eutrophication [69]. Nutrient enrichment can lead to secondary effects on riffle macroinvertebrates, such as excessive algae growth, increases in suspended fine particulate organic matter and sediment retention [95], and subsequent declines in interstitial living space [22] and food quality [96]-[99]. Correspondingly, 
several macroinvertebrate metric responses we observed indicate the effects of these higher nutrients downstream of the WWTF discharge. These include greater dominance of Hydropsychidae Trichoptera $\left(\operatorname{HydT}_{\mathrm{cp}}\right)$, a decline in the scraper/filtering collector ratio $\left(\mathrm{ScFC}_{\text {ratio }}\right)$, and increases in biotic index values $\left(\mathrm{KBI}_{\text {tol }}\right.$ and $\left.\mathrm{MBI}_{\text {tol }}\right)$. Even though these effects may be secondary responses to greater algal biomass caused by the nutrient increase, the response of these metrics to nutrient loading is expected because increased algal growth leads to increases in water column seston, which is fed upon by filtering taxa such as the net-spinning Trichoptera (Hydropsychidae). Filtering Trichoptera taxa are generally more pollution tolerant than the other Trichoptera taxa found at our upstream site (site 1), and their dominance increased below the WWTF discharge. This is also supported by our April data for abundance of filtering macroinvertebrates (Filt $t_{\mathrm{fh}}$ ), which was significantly greater at the site directly below the WWTF discharge (site $2, \mathrm{p}=0.002$, Table 2 ) as compared to the other two sites. Further, the two biotic indices included in this assessment ( $\mathrm{KBI}_{\text {tol }}$ and $\mathrm{MBI}_{\text {tol }}$ ) responded in the expected direction (values increased with increasing nutrient enrichment), and both are calculated based on macroinvertebrate tolerances to nutrient loading in streams [100] [101]. We found all of the aforementioned metrics to be important components in at least one of the significant regression models selected for predicting degree of attainment in biotic condition (Table 3).

Several studies have reported effects of wastewater discharges on macroinvertebrate communities, and some of these are related to documenting recovery after facilities were upgraded from primary to secondary treatment [93] [102] [103] as opposed to measuring conditions after implementation of advanced biological nutrient removal as in our study [69]. Reference [103] concluded that EPT taxa richness was the best indicator response metric to measure recovery of the White River when Indianapolis, IN upgraded their WWTF's to advanced treatment in the 1980's. Even though some studies have documented an overall increase in macroinvertebrate biomass or abundance below WWTF discharges [104], most studies have reported negative effects on species richness and composition. These include declines in scraper/grazers [105], declines in EPT taxa [43], increases in Hydropsychidae Trichopera [45], and increases in abundance of nutrient-tolerant taxa such as the tendipid midge Dicrotendipes and orthoclad midges in the Cricotopus/Orthocladius species complexes [106]-[108], all of which we observed at our two study sites downstream of the discharge. In addition to macroinvertebrates, these discharges are also known to cause species loss and/or decrease of diatoms [93], alteration of microbial activity [109] and a decline in food quality for terrestrial insectivores such as bats [48]. Overall, the available literature suggests that WWTF discharges stimulate autotrophy and heterotrophy, leading to loss of aquatic macroinvertebrate taxa and increase in dominance of tolerant species [34] [93].

Even though previous studies have indicated that much of the nutrients entering urban watersheds originate from periodic stormwater runoff (precipitation) events, this nutrient source is not continuous as is the case with wastewater discharges. Reference [44] found that stormwater runoff was more important than WWTF's in explaining observed increases in contaminants, which can often be associated with these discharges [110] [111]. Reference [99] found that changes in resource quality may favor faster growing or shorter-lived species, and a negative relationship between diversity and nutrient concentrations. Other researchers have also indicated that nutrients originating from stormwater have less chance of being utilized as an energy source because runoff events often coincide with periods of high turbidity which can reduce photosynthetic and metabolic processes. In fact, nutrient research indicates that a majority of nitrogen in the turbid lower Missouri River passes through to the Mississippi River without being utilized [112] [113]. This is further supported by [34], who reported low nutrient retention downstream of WWTF's in relation to the high concentrations present. Reference [93] found a similar response in the Little Miami R. in Ohio, with a percent effluent $(15 \%-35 \%)$ similar to that observed during base flows in our study [69]. In contrast, discharges from WWTF's provide a continuous source of clarified nutrient-rich water during dry conditions, leaving more opportunities for localized excessive algal growth and substrate fouling, two of the conditions we observed at our most downstream site during our evaluation of stream habitat quality that accompanied the overall study [69]. Other macroinvertebrate studies conducted below WWTF discharges indicate that except during higher flows that dilute these discharges, low flow conditions are unfavorable for survival of some EPT taxa [114]. We did not attribute loss of EPT taxa or changes in composition to water temperature because of the small magnitude in site differences we observed; under most conditions and seasons, differences between site 1 and site 3 were approximately $1^{\circ} \mathrm{C}$ or less [69].

In addition to nutrient loading, factors such as sedimentation and habitat instability are also known to alter the functional composition of macroinvertebrates in streams, and some responses of macroinvertebrate functional feeding group metrics we observed in this study at least partially supports this conclusion. Literature indicates 
that altered fluvial processes as a result of urbanization and resulting habitat degradation may be more important than toxicity or organic loading [115], and that sedimentation associated with urbanization may cause more widespread effects than nutrient increases [116]. Reference [22] found even moderate levels of sedimentation can cause a decline in some scraper/grazer taxa. Further, scrapers are known to be negatively affected by other stressors associated with increased urbanization, even in streams that do not have WWTF discharges [79] [117]. Habitat scores for canopy cover and riparian buffer widths were lower at the most downstream site [69], and previous research suggests that streams with more open canopy cover, increased sunlight availability and concentrations of nutrients, should yield a decrease in shredder abundance and an increase in scraper/grazer abundance [118]-[120]. We did observe lower abundance of shredders at our most downstream site in April, however scraper abundance declined at downstream sites in comparison to the upstream site based on August data. These changes may be secondary responses to nutrient loading, because excess nutrients can reduce shredder food availability through increased leaf litter breakdown rates [3] [30] [121] and increases in algae growth can result in higher food availability for scraper/grazer macroinvertebrates [118] [120]. Available literature suggests that scrapers do increase at intermediate levels of algae biomass, but when this growth increases to the point where periphyton becomes embedded with fine sediment particles, this food source becomes less palatable to scraper macroinvertebrates [122]. Similarly, substantial decreases in scraper abundance have been demonstrated as a result of chemical contamination in periphytic algae [123] and fungal growth on leaf surfaces [124] [125], both of which are fed upon by macroinvertebrates belonging to this functional group. These conclusions, taken together with our overall study results, suggests that the decline in scraper macroinvertebrates at site 3 may be a secondary toxic response related to water column contamination of substrate food materials (periphyton and/or aquatic fungal growth), excessive algal growth in riffles due to nutrient increases and a more open canopy, or a combination of both. We also documented responses in percent filterers (Filt $t_{\mathrm{fh}}$ ), which significantly increased at the site immediately downstream of the discharge (site 2) in April.

Reference [96] found that urban streams mainly support macroinvertebrates adapted to rapidly changing flow and unstable, erosional substrates, or those that use low-quality transient food sources. This is supported by our significant decline in the ratio of scrapers to filtering collectors $\left(\mathrm{ScFC}_{\text {ratio }}\right)$ directly downstream of the WWTF discharge during both time periods (Table 2). For the same reasons, we also expected a response in metrics associated with macroinvertebrate clingers (richness $=\mathrm{ClingR}_{\mathrm{fh}}$, abundance $=\mathrm{ClingP}_{\mathrm{fh}}$ ) which commonly colonize root mats and overhanging vegetation along stream margins. A decline in these metrics at sites downstream of the WWTF discharge might be expected due to our estimates of greater exposed channel substrates during base flow conditions at these sites [69]. It is possible that root mats and overhanging vegetation along stream margins may either become frequently disturbed during scouring periods of higher runoff, or may not be inundated long enough to provide habitat for clinging macroinvertebrates during low flows. Even though the $\mathrm{ClingR}_{\mathrm{fh}} \mathrm{metric}_{\mathrm{c}}$ was chosen by STEPWISE and included in one of the significant regression models, we did not observe statistically significant differences among sites for the two clinger metrics during either time period.

Watershed scale parameters associated with land use are important in shaping aquatic community assemblages in streams [44] [65] [126] [127]. Available literature has documented declines in macroinvertebrate species richness in the absence of WWTF discharges, both with increases in urban land cover [122], impervious surfaces [8] [60] [61] [128] [129], urban intensity [39] [130], habitat loss [131] and nutrient enrichment from sources other than WWTF discharges [99] [132]. In their study of streams receiving WWTF discharges, [43] found significantly fewer mayfly taxa, total taxa, and Tanytarsini midges in urban streams as compared to rural streams, suggesting that simultaneous land use changes associated with urbanization may contribute additional nutrients when these sources occur simultaneously. Supporting literature indicates that even in the absence of elevated concentrations of toxins, nutrient increases due to urban runoff can still cause elimination of sensitive species and increase in dominance of nutrient-tolerant taxa [132]. Other studies have suggested that previous land use changes that occurred before modern approaches in bioassessments were implemented may mask the effects of other stressors, and that these legacy effects may be much longer lasting than currently observed impacts [39]. Similarly, reference [133] found that land use in the 1950's was the best predictor of present-day diversity in stream ecosystems. However, these studies may not be directly applicable to local scale changes that might be expected from distinct point sources, and land cover variables such as impervious surfaces are often considered as surrogates for predicting responses at the watershed scale [134] [135].

Among studies where degradation of aquatic communities has been documented in urban streams, some have reported thresholds at which biological effects begin to occur. For example, thresholds for percent impervious 
surface cover range from as low as 5\% - 7\% for coldwater streams [61] [136]-[138] and a range of $8 \%$ - 15\% among studies conducted in warmwater streams [60] [139]-[143]. Our estimates of impervious surface cover between site 1 (5.8\%) and site $3(7.7 \%)$ fall within the lower range of these studies [69] and suggests that this threshold may be considerably lower than the $10 \%$ level most commonly reported in several of these studies. Therefore, the WWTF discharge in our study may be lowering the expected threshold for effects of other watershed variables. Similarly, thresholds for reach or segment-scale variables have also been reported, including nutrient assimilation [119] and habitat quality measures [115] [144]. In our study, nutrient concentrations at the two downstream study sites [69] were comparable to thresholds ranging from 0.86 - $1.92 \mathrm{mg}$ total nitrogen (TN)/L determined by other research studies [99] [145] [146], whereas the $0.61 \mathrm{mg} / \mathrm{L}$ value reported by [119] was closer to values we observed at our upstream site. Similarly, previous investigators have demonstrated that localized reach-scale parameters and riparian land use in the immediate radial buffer zone are better predictors of biological effects than watershed-scale land cover measurements [38] [127] [147]. Our results at least partially support this conclusion, because urban land cover and impervious surface cover change rapidly in the localized region adjacent to our $10.7 \mathrm{~km}$ study reach. We calculated these parameters for the intervening area [69] to demonstrate this localized land use change and provide comparisons with overall watershed-scale estimates. Within the intervening area (defined as the watershed area contributing to the stream between site 1 and site 3), impervious surfaces were nearly twice that of the total watershed area above site 3 (13.7\% vs. $7.7 \%)$, and urban land cover was nearly $10 \%$ higher (34.3\% vs. $25.8 \%$ ), indicating that these land cover variables are rapidly changing within our study segment. Even though the observed differences in watershed-scale estimates of these parameters between the upstream and most downstream site do not appear large, these localized changes may be contributing to an increase in stormwater runoff within our study reach. However, we did not quantify the degree of stormwater connectivity within the intervening area, which may have improved our interpretations regarding the causes and sources of these contributing stressors and corresponding biological effects we observed. Considering these factors, it is likely that biological effects associated with the nutrients contributed by the WWTF discharge may be confounding any conclusions related to impervious surface thresholds. Further, it is apparent that our study would have benefitted from a more detailed examination of stormwater runoff patterns and the partitioning of connected vs. non-connected impervious surface cover, as has been suggested by other research studies conducted in urban streams [129].

Stream quality evaluations in urban waterways often suffer from limitations associated with the presence of multiple co-occurring stressors [53] [54] and the fact that individual metrics often lack the diagnostic ability needed to effectively identify specific causes and sources of impairment in these streams [67]. For example, simultaneous increases in nutrients and fine sediments resulting from both point and non-point sources are often the most commonly observed consequences resulting from urbanization, yet several macroinvertebrate indicator metrics respond similarly to both of these stressors along with a wide variety of other sources of stream degradation [86]. A common approach to this problem has been to integrate several response metrics and develop a multimetric index such as a Benthic Index of Biotic Integrity (B-IBI), to provide a method of scoring or rating the biological condition of a stream site relative to other sites. In comparison to assessments that utilize only one or two metrics, this approach of integrating several metrics into an index not only provides a more robust evaluation, but also may improve diagnostic capability while minimizing metric redundancy and bias [51] [148]-[151]. Previous investigators have suggested utilizing a systematic approach to carefully select metrics for inclusion into an index, so that the negative effects these shortcomings have on assessment results can be reduced. In previous studies, the index development process has included filters or screening tools [67] [152], empirical methods [65] [127] or modeling approaches [44] [66] to determine which indicator metrics best respond to certain stressors. However, most of these studies include indicator response data from many stream sites over large geographic areas to develop multimetric indices that ultimately have broad applicability. Considering this, multimetric indices may also obscure the ability to differentiate causes of individual stressors on biota. In our study, we utilized a 10-metric macroinvertebrate score developed for evaluating eastern Kansas streams because these biotic condition scores for the upper Blue River system were included in previous stream quality evaluations conducted with the same KDHE sampling protocol and during the same seasons of collection [71] [79] [80], and therefore were deemed more appropriate for smaller scale studies such as ours.

In this study, we used responses of indicator metrics to collectively predict the overall level of attainment in biotic condition at the local scale based on optimum conditions (i.e. best documented metric values from previous studies) within the Blue River watershed. Results indicate that our sampling reach attains a biological 
quality ranging from $59.9 \%$ to $86.5 \%$ of the best conditions known to exist within the watershed, and that scores at the site upstream of the discharge indicate that it is most similar in biotic condition to these higher quality sites [71] [79] [80]. This can partly be explained by the presumed loss of 13 EPT taxa downstream of the discharge, because many of these same taxa are present at these previously studied upstream sites that attain the best metric values and scores. In our study, macroinvertebrate metrics related to EPT insect orders were frequently identified in significant site differences, metric selection steps, and multiple regression models. This supports results of other research studies that have concluded both total and EPT taxa richness measures are among the best indicators for factors associated with urbanization [38] [39] [103] [138]. Our significantly higher estimates of intolerant taxa abundance (IntKBI ${ }_{\text {tol }}$ ) upstream of the WWTF discharge during both sampling periods is also supported by others who have found tolerance metrics to be among the most sensitive indicators of nutrient enrichment [66]. Even though this metric was not included in any of the significant regression models we chose to report here, substituting this metric with the other tolerance metrics that were included in our assessment $\left(\mathrm{KBI}_{\text {tol }}\right.$ and $\left.\mathrm{MBI}_{\text {tol }}\right)$ generated highly significant regression coefficients that were only slightly lower than those reported in Table 3. We recognize that relative abundance (composition/\%) metrics may have a higher spatial or temporal variation than metrics in other categories because of the qualitative nature of the KDHE sampling protocol [81]. However, only five metrics from this category were included in the models, and stipulations associated with the field sampling and Kansas protocol outlined in our methods were intended to reduce sorting bias and improve the sample variance and usefulness of relative abundance metrics. Our results indicate that each suite of indicator metrics (i.e. model components) we selected for predicting percent attainment do meet our original goals of representing a wide diversity of community attributes, yet reduce metric redundancy concerns that have been identified by previous multimetric studies [65]. Other studies have also documented responses of several of these metrics to various factors associated with urban streams, including Tany $_{\mathrm{cp}}$, Oligo ${ }_{\mathrm{cp}}$, HydT $\mathrm{T}_{\mathrm{cp}}$, and $\mathrm{EPT}_{\mathrm{cp}}$ [43] [102].

This study utilized the combined percentages of best metric values within the watershed determined from a continuum of 10-metric biotic condition scores in previous macroinvertebrate studies [71] [79] [80] to represent an integrated measure of stream condition and overall biological response for comparatively scoring our study sites. This approach also provided the basis for identifying significant combinations of indicator metrics with relatively low redundancy that can effectively predict the ability of an urban stream site to attain a biotic condition similar to the best known conditions within the watershed. Our observed responses were generally more pronounced in April, partly because some stoneflies (Plecoptera) and caddisflies (Trichoptera) have univoltine and relatively short life cycles with dormant egg stages during summer months [153] [154], and therefore had already emerged from the stream before late summer samples were taken. This seasonality of life cycles may also explain the lack of significant site differences in August for many of the metrics associated with these two insect orders that were significant in April (Table 2). In addition, our significant regression models include combinations of several indicator metrics not previously reported below WWTF discharges, including those related to effects from decreased habitat quality and changes in functional feeding groups $\left(\right.$ Filt $_{\mathrm{fh}}, \mathrm{SC}_{\mathrm{fh}}$, ClingR $\mathrm{fh}$, $\mathrm{ScFc}_{\text {ratio }}$ ), and those related to changes in dominance (PDT1 $1_{\mathrm{dd}}, \mathrm{PDT} 2_{\mathrm{dd}}$ ) or relative abundance of specific indicator groups of macroinvertebrates (Tany ${ }_{\mathrm{cp}}$, Oligo $\mathrm{c}_{\mathrm{cp}}$, $\mathrm{HydT}_{\mathrm{cp}}$, ODNI $\mathrm{ODp}_{\mathrm{c}}$. Even though the regression coefficients of the models we chose are relatively high (>0.95), percent attainment as defined in this paper is not directly correlated to the individual metric values themselves. Therefore, we partially attribute this to the short range in percent attainment values across the metrics we tested. Our goal was to identify meaningful combinations of indicator metrics with low redundancy that are useful for determining percent attainment based on benchmark values from the best available sites in the watershed. The metric combinations and models may be useful for either projecting changes in biotic condition occurring over a relatively short stream segment with a distinct nutrient point source, or eventual development of a multimetric index for evaluating the degree of attainment in biotic condition based on least-disturbed or best available sites within urbanized watersheds. Because of this, our model results may especially be useful in cases where only the downstream reaches of a watershed are urbanized, because upstream and least-disturbed sites within undeveloped, rural areas (as is the case with the Blue River) would be available for making site comparisons similar to ours.

Our data indicates that macroinvertebrate communities in the upper Blue River are responding primarily to longitudinal changes in organic nutrient enrichment, which is further supported by the algae and water quality results from the overall study [69]. The responses we observed suggest that the WWTF discharge is the primary nutrient source within our study reach, even though other stressors related to land use, habitat quality and hy- 
drology may be contributing factors to these responses. At our two most downstream sites, the poor rating of riparian bank protection and subsequent increase in stream substrates exposed in the stream channel during base flow conditions, as well as the higher periphyton biomass, conductivity, turbidity, and water column nutrients [69] are also likely associated with the WWTF discharge. However, the increases in percent urban land cover and impervious surfaces within our study reach, both at the watershed scale and locally within the intervening area, indicate that there are other potential sources of stressors not related to the WWTF discharge. It is possible that our observed longitudinal increases in nutrients may be due to both of these sources occurring simultaneously along the study reach. However, since the WWTF discharge is continuous and other potential nutrient sources such as urban stormwater are intermittent, we would not expect the combined effect of these sources to occur except during precipitation-based runoff events. In addition, biotic condition at our furthest downstream site may also be negatively affected by lower habitat scores for canopy cover and average buffer width. Other studies have reported macroinvertebrate responses to changes in watershed land use, increased impervious surfaces, and habitat conditions that were similar to our study [131] [147] [155]. However, in comparison to these studies, the observed magnitude of change in many of these parameters within our study reach was relatively small.

Based on loss of sensitive EPT taxa and changes in dominance or abundances of ecologically important groups of indicator macroinvertebrates, there is an upstream-to-downstream decline in stream quality indicating a gradient in overall biological condition within our $10.7 \mathrm{~km}$ study segment. Our resulting site scores indicated that during the spring season, relative biological condition at the upstream site (site 1) was significantly greater than the two sites downstream of the WWTF discharge. In addition, the results from the August sampling period identified the site directly downstream of the WWTF discharge as non-supporting of aquatic life based on the multimetric score determined from the four KDHE metrics (Figure 2). This study did not include macroinvertebrate data collection before implementation of biological nutrient removal at the WWTF, which would have allowed temporal comparisons in communities. Reference [102] documented a three year aquatic community recovery period after implementation of advanced treatment, so it is possible that stream conditions may not have reached equilibrium at the time of sampling. However, because part of the WWTF upgrade included a capacity increase as well as biological nutrient removal, the total loading of nutrients was essentially the same as that prior to upgrades [69]. Theoretically, the resulting larger volume of effluent containing lower concentrations of nutrients may counteract the adverse effects of lower flows during summer months, or at least lessen their severity. This premise is supported by other studies that have documented either a lower severity of effects from WWTF discharges when effluent is more diluted [114], or a greater severity during summer months and periods of low flow [44]. One result from our overall study also supports this conclusion, in that at sites downstream of the discharge, stream metabolism was altered by nutrient enrichment only during the summer months when lower flows predominated [69].

\section{Conclusion}

Overall, our study results have potential implications related to the effectiveness of currently available biological nutrient removal technologies. Even though nutrient concentrations were found to be below NPDES permit targets after the upgrades [69], present-day discharges from this facility do not provide an adequate level of aquatic life protection, especially for preventing the loss of EPT taxa. This conclusion is similar to other studies that have documented that urban streams often do not meet warmwater aquatic life criteria [134], especially when WWTF discharges make up a significant portion of the base flow in these streams [40] [41] [156]. Another implication resulting from this study is that combinations of indicator metrics with low redundancy can effectively predict the degree to which an urbanized stream reach can attain the highest known biological condition in a watershed. These metric combinations represent a wide variety of community attributes that respond either directly or indirectly to urban-related stressors, including changes in habitat quality, land use, and functional composition. Also it is the fact of ecological significance that macroinvertebrate communities within our study reach of the Blue River system currently have the ability to recover if a greater level of nutrient removal from WWTF discharges becomes possible in the future. This is because upstream portions of the watershed remain primarily rural, with reaches of relatively high biological condition and containing many of the same taxa not found downstream of the WWTF discharge [69] [71] [79] [80]. Even though our study helped the facility meet permitting requirements associated with the upgrade, it was not designed to evaluate or monitor long-term tem- 
poral effects of the discharge. However, our data taken after implementation suggest that concentrations of nutrients downstream of the WWTF discharge currently remain significant enough to cause adverse effects on macroinvertebrate community structure, and that future implementation of technologies that remove a larger quantity of nutrients from effluent may be required to protect aquatic life in urban waterways that receive these discharges.

\section{Acknowledgements}

The authors thank Susan Pekarek and John Metzler of Johnson County Wastewater for technical assistance and providing data and information about wastewater treatment at the Blue River Main facility. The authors also thank Tony Holt and other staff members of the Johnson County Environmental Laboratory for support in coordination of water-sample analysis. The authors thank Andrea Repinsky of the Mid-America Regional Council for providing land use data and appreciate the help of Keith Landgraf of the USGS Mid-Continent Geographic Science Center with the analysis and interpretation of land use data, and Chad Larson with map development. The authors also appreciate the assistance of Mark Ellersieck, University of Missouri, with the statistical analyses. The authors also thank Amanda H. Bell and two anonymous reviewers for their helpful reviews of earlier versions of the manuscript. Use of proprietary names in this document cannot be considered an endorsement by the U.S. Department of the Interior or the U.S. Geological Survey.

\section{References}

[1] Grimm, N.B., Grove, J.M., Pickett, S.T.A. and Redman, C.L. (2000) Integrated Approaches to Long-Term Studies of Urban Ecological Systems. Bioscience, 50, 571-584. http://dx.doi.org/10.1641/0006-3568(2000)050[0571:IATLTO]2.0.CO;2

[2] Paul, M.J. and Meyer, J.L. (2001) Streams in the Urban Landscape. Annual Review of Ecology and Systematics, 32, 333-365. http://dx.doi.org/10.1146/annurev.ecolsys.32.081501.114040

[3] Meyer, J.L., Paul, M.J. and Taulbee, K. (2005) Stream Ecosystem Function in Urbanizing Landscapes. Journal of the North American Benthological Society, 24, 602-612. http://dx.doi.org/10.1899/0887-3593(2005)024\[0602:SEFIUL\]2.0.CO;2

[4] Sheehan, M.O. (2001) City Limits: Putting the Brakes on Sprawl. Worldwatch Paper No. 156, Worldwatch Institute, Washington DC.

[5] Cohen, J.E. (2003) Human Population: The Next Half Century. Science, 302, 1172-1175. http://dx.doi.org/10.1126/science.1088665

[6] Roesner, L.A., Ed. (1997) Effects of Watershed Development and Management on Aquatic Ecosystems. In: Proceedings of an Engineering Foundation Conference, American Society of Civil Engineers, New York, 384.

[7] Finkenbine, J.K., Atwater, J.W. and Mavinic, D.S. (2000) Stream Health after Urbanization. Journal of the American Water Resources Association, 36, 1149-1160. http://dx.doi.org/10.1111/j.1752-1688.2000.tb05717.x

[8] Walsh, C.R., Roy, A.H., Feminella, J.W., Cottingham, P.D., Groffman, P.M. and Morgan II, R.P. (2005) The Urban Stream Syndrome: Current Knowledge and a Search for a Cure. Journal of the North American Benthological Society, 24, 706-723. http://dx.doi.org/10.1899/0887-3593(2005)024\[0706:TUSSCKI]2.0.CO;2

[9] Dailey, G. (1997) Nature’s Services: Societal Dependence on Natural Ecosystems. Island Press, Covelo.

[10] Bolund, P. and Hunhammer, S. (1999) Ecosystem Services in Urban Areas. Ecological Economics, 29, $293-301$. http://dx.doi.org/10.1016/S0921-8009(99)00013-0

[11] Palmer, M., Bernhardt, E., Chornesky, E., Collins, S., Dobson, A., Duke, C., Gold, B., Jacobson, R., Kingsland, S., Krantz, R., Mappin, M., Martinez, M.L., Micheli, F., Morse, J., Pace, M., Pascual, M., Palumbi, S., Reichman, O.J., Simons, A., Townsend, A. and Turner, M. (2004) Ecology for a Crowded Planet. Science, 304, 1251-1252. http://dx.doi.org/10.1126/science.1095780

[12] Anton, P.A. (2005) The Economic Value of Open Space: Implications for Land Use Decisions. Wilder Research Publ., St. Paul.

[13] Netusil, N.R. (2006) Economic Valuation of Riparian Corridors and Upland Wildlife Habitat in an Urban Watershed. Journal of Contemporary Water Research \& Education, 134, 39-45. http://dx.doi.org/10.1111/j.1936-704x.2006.mp134001008.x

[14] Berkowitz, A.R., Nilon, C.H. and Hollweg, K.S., Eds. (1999) Understanding Urban Ecosystems: A New Frontier for Science and Education. Springer-Verlag, New York. 
[15] Groffman, P.M. (2003) Down by the Riverside: Urban Riparian Ecology. Frontiers in Ecology and the Environment, 1, 315-321. http://dx.doi.org/10.1890/1540-9295(2003)001[0315:DBTRUR]2.0.CO;2

[16] McGranahan, G. and Satterthwaite, D. (2003) Urban Centers: An Assessment of Sustainability. Annual Review of Environment and Resources, 28, 243-274. http://dx.doi.org/10.1146/annurev.energy.28.050302.105541

[17] US Environmental Protection Agency (2000) The Quality of Our Nations Waters: Report to Congress. EPA 841-S-00-001, USEPA, Washington DC.

[18] Morley, S.A. and Karr, J.R. (2002) Assessing and Restoring the Health of Urban Streams in the Puget Sound Basin. Conservation Biology, 16, 1498-1509. http://dx.doi.org/10.1046/j.1523-1739.2002.01067.x

[19] Kansas Department of Health and Environment (2004) Surface Water Nutrient Reduction Plan. Bureau of Water, Topeka.

http://water.epa.gov/scitech/swguidance/standards/criteria/nutrients/upload/Kansas-SURFACE-WATER-NUTRIENTREDUCTION-PLAN-DECEMBER-29-2004.pdf

[20] Kansas Department of Health and Environment (2012) 2012 303(d) List of Impaired Waters. http://www.kdheks.gov/tmdl/2012/303d_List_Long.pdf

[21] US Environmental Protection Agency (2009) National Water Quality Inventory: Report to Congress, EPA 841-R-08001, USEPA Office of Water, Washington DC.

[22] Broekhuizen, N., Parkyn, S. and Miller, D. (2001) Fine Sediment Effects on Feeding and Growth in the Invertebrate Grazers Potamopyrgus antipodarum (Gastropoda, Hydrobiidae) and Deleatidium sp. (Ephemeroptera, Leptophlebiidae). Hydrobiologia, 457,125-132. http://dx.doi.org/10.1023/A:1012223332472

[23] Horner, R.R., Welch, E.B. and Veenstra, R.B. (1983) Development of Nuisance Periphytic Algae in Laboratory Streams in Relation to Enrichment and Velocity. In: Wetzel, R.G., Ed., Periphyton of Freshwater Ecosystems, Dr. W. Junk Publ., The Hague, 121-131. http://dx.doi.org/10.1007/978-94-009-7293-3_18

[24] Quinn, J.M. and Hickey, C.W. (1990) The Magnitude of the Effects of Substrate Particle Size, Recent Flooding, and Catchment Development on Benthic Invertebrates in 88 New Zealand Rivers. New Zealand Journal of Marine and Freshwater Research, 24, 411-427. http://dx.doi.org/10.1080/00288330.1990.9516433

[25] Wharfe, J.R., Taylor, K.S. and Montgomery, H.A.C. (1984) The Growth of Cladophora glomerata in a River Receiving Sewage Effluent. Water Research, 18, 971-979. http://dx.doi.org/10.1016/0043-1354(84)90247-1

[26] Welch, E.B., Jacoby, J.M., Horner, R.R. and Seeley, M.R. (1988) Nuisance Biomass Levels of Periphytic Algae in Streams. Hydrobiologia, 157, 161-168. http://dx.doi.org/10.1007/bf00006968

[27] Carpenter, S.R., Caraco, N.F., Correll, D.L., Howarth, R.W., Sharpley, A.N. and Smith, V.H. (1998) Nonpoint Pollution of Surface Waters with Phosphorus and Nitrogen. Ecological Applications, 8, 559-568. http://dx.doi.org/10.1890/1051-0761(1998)008[0559:NPOSWW]2.0.CO;2

[28] Smith, V.H., Tillman, G.D. and Nekola, J.C. (1999) Eutrophication: Impacts of Excessive Nutrient Inputs on Freshwater, Marine and Terrestrial Ecosystems. Environmental Pollution, 100, 179-196. http://dx.doi.org/10.1016/S0269-7491(99)00091-3

[29] Dodds, W.K. (2006) Eutrophication and Trophic State in Rivers and Streams. Limnology and Oceanography, 51, 671680. http://dx.doi.org/10.4319/lo.2006.51.1_part_2.0671

[30] Gulis, V. and Suberkropp, K. (2003) Leaf Litter Decomposition and Microbial Activity in Nutrient-Enriched and Unaltered Reaches of a Headwater Stream. Freshwater Biology, 48, 123-134. http://dx.doi.org/10.1046/j.1365-2427.2003.00985.x

[31] Ulseth, A.J. and Hershey, A.E. (2005) Natural Abundances of Stable Isotopes Trace Anthropogenic N and C in an Urban Stream. Journal of the North American Benthological Society, 24, 270-289. http://dx.doi.org/10.1899/03-080.1

[32] Northington, R.M. and Hershey, A.E. (2006) Effects of Stream Restoration and Wastewater Treatment Plant Effluent on Fish Communities in Urban Streams. Freshwater Biology, 51, 1959-1973. http://dx.doi.org/10.1111/j.1365-2427.2006.01626.x

[33] Chadwick, M.A., Dobberfuhl, D.R., Benke, A.C., Huryn, A.D., Suberkropp, K. and Thiele, J.E. (2006) Urbanization Affects Stream Ecosystem Function by Altering Hydrology, Chemistry, and Biotic Richness. Ecological Applications, 16, 1796-1807. http://dx.doi.org/10.1890/1051-0761(2006)016[1796:UASEFB]2.0.CO;2

[34] Gücker, B., Brauns, M. and Pusch, M.T. (2006) Effects of Wastewater Treatment Plant Discharge on Ecosystem Structure and Function of Lowland Streams. Journal of the North American Benthological Society, 25, 313-329. http://dx.doi.org/10.1899/0887-3593(2006)25[313:EOWTPD]2.0.CO;2

[35] Young, R.G., Matthaei, C.D. and Townsend, C.R. (2008) Organic Matter Breakdown and Ecosystem Metabolism: Functional Indicators for Assessing River Ecosystem Health. Journal of the North American Benthological Society, 27, 605-625. http://dx.doi.org/10.1899/07-121.1 
[36] Frenzel, S.A. (1990) Effects of Municipal Wastewater Discharges on Aquatic Communities, Boise River, Idaho. Journal of the American Water Resources Association, 26, 279-287. http://dx.doi.org/10.1111/j.1752-1688.1990.tb01371.x

[37] Allen, J.D. (2004) Landscapes and Riverscapes: The Influence of Land Use on Stream Ecosystems. Annual Review of Ecology, Evolution, and Systematics, 35, 257-284. http://dx.doi.org/10.1146/annurev.ecolsys.35.120202.110122

[38] Deacon, J.R., Soule, S.A. and Smith, T.E. (2005) Effects of Urbanization on Stream Quality at Selected Sites in the Seacoast Region in New Hampshire, 2001-03. US Geological Survey Scientific Investigations Report 2005-5103.

[39] Cuffney, T.F., Brightbill, R.A., May, J.T. and Waite, I.R. (2010) Responses of Benthic Macroinvertebrates to Environmental Changes Associated with Urbanization in Nine Metropolitan Areas. Ecological Applications, 20, 1384-1401. http://dx.doi.org/10.1890/08-1311.1

[40] Lee, C.J., Mau, D.P. and Rasmussen, T.J. (2005) Effects of Nonpoint and Selected Point Contaminant Sources on Stream-Water Quality and Relation to Land Use in Johnson County, Northeastern Kansas, October 2002 to June 2004. US Geological Survey Scientific Investigations Report 2005-5144.

[41] Wilkison, D.H., Armstrong, D.J., Norman, R.D., Poulton, B.C., Furlong, E.T. and Zaugg, S.D. (2006) Water-Quality in the Blue River Basin, Kansas City Metropolitan Area, Missouri and Kansas, July 1998 to October 2004. US Geological Survey Scientific Investigations Report 2006-5147.

[42] Suozzo, K. (2005) The Use of Aquatic Insects and Benthic Macroinvertebrate Communities to Assess Water Quality Upstream and Downstream of the Village of Stamford Wastewater Treatment Facility. In: Proceedings of the 38th Annual Report of the SUNY Oneonta Biological Field Station, Biological Field Station, Cooperstown, 141-151.

[43] Dyer, S.D. and Wang, X. (2002) A Comparison of Stream Biological Responses to Discharge from Wastewater Treatment Plants in High and Low Population Density Areas. Environmental Toxicology and Chemistry, 21, 1065-1075. http://dx.doi.org/10.1002/etc.5620210524

[44] Kosmala, A., Charvet, S., Roger, M.C. and Faessel, B. (1999) Impact Assessment of a Wastewater Treatment Plant Effluent Using Instream Invertebrates and the Ceriodaphnia dubia Chronic Toxicity Test. Water Research, 33, 266-278. http://dx.doi.org/10.1016/S0043-1354(98)00176-6

[45] Suckling, D.M. (1982) Organic Wastewater Effects on Benthic Invertebrates in the Manawatu River. New Zealand Journal of Marine and Freshwater Research, 16, 263-270. http://dx.doi.org/10.1080/00288330.1982.9515969

[46] Fukushima, S. and Kanada, S. (1999) Effects of Chlorine on Periphytic Algae and Macroinvertebrates in a Stream Receiving Treated Sewage as Maintenance Water. Japanese Journal of Limnology, 60, 569-583. http://dx.doi.org/10.3739/rikusui.60.569

[47] Pascoal, C., Cassio, F., Marcotegui, A., Sanz, B. and Gomes, P. (2005) Role of Fungi, Bacteria, and Invertebrates in Leaf Litter Breakdown in a Polluted River. Journal of the North American Benthological Society, 24, 784-797. http://dx.doi.org/10.1899/05-010.1

[48] Kalcounis-Rueppell, M.C., Payne, V.H., Huff, S.R. and Boyko, A.L. (2007) Effects of Wastewater Treatment Plant Effluent on Bat Foraging Ecology in an Urban Stream. Biological Conservation, 138, 120-130. http://dx.doi.org/10.1016/j.biocon.2007.04.009

[49] Stuetz, R. and Frechen, F. (2001) Odours in Wastewater Treatment: Measurement, Modeling and Control. IWA Publ., London.

[50] Rosenberg, D.M. and Resh, V.H. (1993) Introduction to Freshwater Biomonitoring and Benthic Macroinvertebrates. In: Rosenberg, D.M. and Resh, V.H., Eds., Freshwater Biomonitoring and Benthic Macroinvertebrates, Chapman/Hall, New York, 1-9.

[51] Davis, W.S. and Simon, T.P., Eds. (1995) Biological Assessment and Criteria-Tools for Water Resource Planning and Decision Making. Lewis Publ., Boca Raton.

[52] Cairns Jr., J. and Pratt, J.R. (1993) A History of Biological Monitoring Using Benthic Macroinvertebrates. In: Rosenberg, D.M. and Resh, V.H., Eds., Freshwater Biomonitoring and Benthic Macroinvertebrates, Chapman/Hall, New York, 10-27.

[53] Culp, J.M. and Baird, D.J. (2006) Establishing Cause-Effect Relationships in Multi-Stressor Environments. In: Hauer, F.R. and Lamberti, G.A., Eds., Methods in Stream Ecology, 2nd Edition, Elsevier, Oxford, 835-854.

[54] Folt, C.L., Chen, C.Y., Moore, M.V. and Burnaford, J. (1999) Synergism and Antagonism among Multiple Stressors. Limnology and Oceanography, 44, 864-877. http://dx.doi.org/10.4319/lo.1999.44.3_part_2.0864

[55] DeShon, J.E. (1995) Development and Application of the Invertebrate Community Index (ICI). In: Davis, W.S. and Simon, T.P., Eds., Biological Assessment and Criteria-Tools for Water Resource Planning and Decision Making, Lewis Publ., Boca Raton, 217-244.

[56] Yoder, C.O. and Rankin, E.T. (1995) Biological Response Signatures and the Area of Degradation Value: New Tools for Interpreting Multimetric Data. In: Davis, W.S. and Simon, T.P., Eds., Biological Assessment and Criteria-Tools for Water Resource Planning and Decision Making, Lewis Publ., Boca Raton, 263-286. 
[57] Kerans, B.L. and Karr, J.R. (1994) A Benthic Index of Biotic Integrity (B-IBI) for Rivers of the Tennessee Valley. Ecological Applications, 4, 768-785. http://dx.doi.org/10.2307/1942007

[58] Karr, J.R., Fausch, K.D., Angermeier, P.L., Yant, P.R. and Schlosser, L.J. (1986) Assessing Biological Integrity in Running Waters: A Method and Its Rationale. Illinois Natural History Survey Pub., Champaign.

[59] Karr, J.R. and Chu, E.W. (1999) Restoring Life in Running Waters: Better Biological Monitoring. Island Press, Washington DC.

[60] Klein, R.D. (1979) Urbanization and Stream Quality Impairment. Journal of the American Water Resources Association, 15, 119-126. http://dx.doi.org/10.1111/j.1752-1688.1979.tb01074.x

[61] Wang, L., Lyons, J. and Kanehl, P. (2001) Impacts of Urbanization on Stream Habitat and Fish across Multiple Spatial Scales. Environmental Management, 28, 255-266. http://dx.doi.org/10.1007/s0026702409

[62] Simon, T.P. (1991) Development of Ecoregion Expectations for the Index of Biotic Integrity I: Central Corn Belt Plain. EPA 905-9-91-025, USEPA Region 5, Chicago.

[63] Bruns, D.A. (2005) Macroinvertebrate Response to Land Cover, Habitat, and Water Chemistry in a Mining-Impacted River Ecosystem: A GIS Watershed Analysis. Aquatic Sciences, 67, 403-423. http://dx.doi.org/10.1007/s00027-005-0792-3

[64] Karr, J.R. (1998) Rivers as Sentinels: Using the Biology of Rivers to Guide Landscape Management. In: Naiman, R.J. and Bilby, R.E., Eds., River Ecology and Management: Lessons from the Pacific Coastal Ecoregion, Springer-Verlag, New York, 502-528. http://dx.doi.org/10.1007/978-1-4612-1652-0 20

[65] Weigel, B.M., Henne, L.J. and Martinez-Rivera, L.M. (2002) Macroinvertebrate-Based Index of Biotic Integrity for Protection of Streams in West-Central Mexico. Journal of the North American Benthological Society, 21, 686-700. http://dx.doi.org/10.2307/1468439

[66] Yuan, L.L. and Norton, S.B. (2003) Comparing Responses of Macroinvertebrate Metrics to Increasing Stress. Journal of the North American Benthological Society, 22, 308-322. http://dx.doi.org/10.2307/1468000

[67] Purcell, A.H., Bressler, D.W., Paul, M.J., Barbour, M.T., Rankin, E.T., Carter, J.L. and Resh, V.H. (2009) Assessment Tools for Urban Catchments: Developing Biological Indicators Based on Benthic Macroinvertebrates. Journal of the American Water Resources Association, 45, 306-319. http://dx.doi.org/10.1111/j.1752-1688.2008.00279.x

[68] Hering, D., Johnson, R.K., Kramm, S., Schmutz, S., Szoszkiewicz, K. and Verdonschot, P.F.M. (2006) Assessment of European Streams with Diatoms, Macrophytes, Macroinvertebrates and Fish: A Comparative Metric-Based Analysis of Organism Response to Stress. Freshwater Biology, 51, 1757-1785. http://dx.doi.org/10.1111/j.1365-2427.2006.01610.x

[69] Graham, J.L., Stone, M.L., Rasmussen, T.J. and Poulton, B.C. (2010) Effects of Wastewater Effluent Discharge and Treatment Facility Upgrades on Environmental and Biological Conditions of the Upper Blue River, Johnson County, Kansas and Jackson County, Missouri, January 2003 through March 2009. US Geological Survey Scientific Investigations Report 2010-5248.

[70] US Census Bureau (2010) State and County Quickfacts. http://quickfacts.census.gov/qfd/states/20000.html

[71] Rasmussen, T.J., Stone, M.S., Poulton, B.C. and Graham, J.L. (2012) Quality of Streams in Johnson County, Kansas, 2002-10. US Geological Survey Scientific Investigations Report 2012-5279.

[72] Johnson County Wastewater (2007) Statistical Report, 20. http://www.jocogov.org/sites/default/files/documents/APR/State\%20Perspective\%202007.pdf

[73] Johnson County Wastewater (2008) Annual Report, 30. http://www.jocogov.org/sites/default/files/documents/APR/2008\%20APR\%20Annual\%20Report.pdf

[74] Tchobanoglous, G., Burton, F.L. and Stensel, H.D. (2003) Wastewater Engineering, Treatment and Reuse. 4th Edition, McGraw-Hill, Boston.

[75] Kansas Department of Health and Environment (2008) Kansas Integrated Water Quality Assessment. Bureau of Water, Topeka. http://www.kdheks.gov/befs/download/2008IR_040108FINAL.pdf

[76] Missouri Department of Natural Resources (2010) Missouri Surface Water Quality Report. Section 305(b) and Proposed 2010 Missouri 303(d) List, Jefferson City. http://dnr.mo.gov/env/wpp/waterquality/305b/docs/2010-305b-report.pdf

[77] Kansas Department of Health and Environment (2008) Kansas Administrative Regulations (KAR), Title 28, Article 16, Surface Water Quality Standards 2008. Secretary of State, Topeka.

[78] Wilkison, D.H., Armstrong, D.A. and Hampton, S.A. (2009) Character and Trends of Water Quality in the Blue River Basin, Kansas City Metropolitan Area, Missouri and Kansas, 1998 through 2007. US Geological Survey Scientific Investigations Report 2009-5169.

[79] Poulton, B.C., Rasmussen, T.J. and Lee, C.J. (2007) Assessment of Biological Conditions at Selected Stream Sites in 
Johnson County, Kansas and Cass and Jackson Counties, Missouri, 2003 and 2004. US Geological Survey Scientific Investigations Report 2007-5108.

[80] Rasmussen, T.J., Poulton, B.C. and Graham, J.L. (2009) Quality of Streams in Johnson County, Kansas, and Relations to Environmental Variables, 2003-07. US Geological Survey Scientific Investigations Report 2009-5235.

[81] Kansas Department of Health and Environment (2000) Division of Environment, Quality Management Plan, Part III-Stream Biological Monitoring Program, Quality Assurance Management Plan. Bureau of Environmental Field Services, Technical Services Section, Topeka.

[82] Merritt, R.W., Cummins, K.W. and Berg, M.B., Eds. (2008) Aquatic Insects of North America. 4th Edition, Kendall/Hunt, Dubuque.

[83] Thorp, J.H. and Covich, A.P. (1991) Ecology and Classification of North American Freshwater Invertebrates. Academic Press, San Diego.

[84] Moulton II, S.R., Carter, J.L., Grotheer, S.A., Cuffney, T.F. and Short, T.M. (2000) Methods of Analysis by the US Geological Survey National Water Quality Laboratory: Processing, Taxonomy, and Quality Control of Benthic Macroinvertebrate Samples. US Geological Survey Open File Report 2000-212.

[85] Moulton II, S.R., Kennen, J.G., Goldstein, R.M. and Hambrook, J.A. (2002) Revised Protocols for Sampling Algal, Invertebrate, and Fish Communities as Part of the National Water-Quality Assessment Program. US Geological Survey Open File Report 2002-150.

[86] Barbour, M.T., Gerritsen, J., Snyder, B.D. and Stribling, J.B. (1999) Rapid Bioassessment Protocols for Use in Streams and Wadeable Rivers-Periphyton, Benthic Macroinvertebrates, and Fish. 2nd Edition, EPA 841/B-99/002, USEPA, Washington DC.

[87] Cuffney, T.F. (2003) User's Manual for the National Water-Quality Assessment Program Invertebrate Data Analysis System (IDAS) Software: Version 3. US Geological Survey National Water-Quality Assessment Program 2003-172.

[88] Maret, T. (1988) A Stream Inventory Process to Classify Use Support and Develop Biological Standards in Nebraska. In: Simon, T.P., Holst, L.L. and Shepard, L.J., Eds., Proceedings of the First National Workshop on Biocriteria, Lincolnwood, Illinois, EPA 905-9-89-003, USEPA Region 5, Chicago, 55-66.

[89] Hite, R.L. and Bertrand, B.A. (1989) Biological Stream Characterization (BSC): A Biological Assessment of Illinois Stream Quality. IEPA/WPC89-275, Special Report 13, Illinois Environmental Protection Agency, Springfield.

[90] Osborne, L.L., Kohler, S.L., Bayley, B.P., Day, D.M., Bertrand, W.A., Wiley, M.J. and Sauer, R. (1992) Influence of Stream Location in a Drainage Network on the Index of Biotic Integrity. Transactions of the American Fisheries Society, 121, 635-643. http://dx.doi.org/10.1577/1548-8659(1992)121<0635:IOSLIA>2.3.CO;2

[91] SAS Institute (2009) SAS/STAT® 9.2 User’s Guide. 2nd Edition, SAS Institute Inc., Cary.

[92] Snedecor, G.W. and Cochran, W.G. (1982) Statistical Methods. 7th Edition, Iowa State Press, Ames.

[93] Lewis, M.A. (1986) Impact of a Municipal Wastewater Effluent on Water Quality, Periphyton, and Invertebrates in the Little Miami River near Xenia, Ohio. Ohio Journal of Science, 86, 2-8.

[94] Davies, S.P. and Jackson, S.K. (2006) The Biological Condition Gradient-A Conceptual Model for Interpreting Detrimental Change in Aquatic Ecosystems. Ecological Applications, 16, 1251-1266. http://dx.doi.org/10.1890/1051-0761(2006)016[1251:TBCGAD]2.0.CO;2

[95] Graham, A.A. (1990) Siltation of Stone-Surface Periphyton in Rivers by Clay-Sized Particles from Low Concentrations in Suspension. Hydrobiologia, 199, 107-115. http://dx.doi.org/10.1007/BF00005603

[96] Pedersen, E.R. and Perkins, M.A. (1986) The Use of Benthic Invertebrate Data for Evaluating Impacts of Urban Runoff. Hydrobiologia, 139, 13-22. http://dx.doi.org/10.1007/BF00770238

[97] Gafner, K. and Robinson, C.T. (2007) Nutrient Enrichment Influences the Responses of Stream Macroinvertebrates to Disturbance. Journal of the North American Benthological Society, 26, 92-102. http://dx.doi.org/10.1899/0887-3593(2007)26[92:NEITRO]2.0.CO;2

[98] Singer, G.A. and Battin, T.J. (2007) Anthropogenic Subsidies Alter Consumer-Resource Stoichiometry, Biodiversity, and Food Chains. Ecological Applications, 17, 376-389. http://dx.doi.org/10.1890/06-0229

[99] Evans-White, M.A., Dodds, W.K., Huggins, D.G. and Baker, D.S. (2009) Thresholds in Macroinvertebrate Biodiversity and Stoichiometry across Water-Quality Gradients in Central Plains (USA) Streams. Journal of the North American Benthological Society, 28, 855-868. http://dx.doi.org/10.1899/08-113.1

[100] Huggins, D.G. and Moffett, M.F. (1988) Proposed Biotic and Habitat Indices for Use in Kansas Streams. Kansas Biological Survey Report 35, Lawrence.

[101] Davenport, T.E. and Kelly, M.H. (1983) Water Resource Data and Preliminary Trend Analysis for the Highland Silver Lake Monitoring and Evaluation Project, Madison County, IL, Phase II. Illinois Environmental Protection Agency IEPA/WPC/83-013, Springfield. 
[102] Crawford, C.G., Wangsness, D.J. and Martin, J.D. (1992) Recovery of Benthic-Invertebrate Communities in the White River near Indianapolis, Indiana, USA, Following Implementation of Advanced Treatment of Municipal Wastewater. Archiv für Hydrobiologie, 126, 67-84.

[103] Lydy, M.J., Crawford, C.G. and Frey, J.W. (2000) A Comparison of Selected Diversity, Similarity and Biotic Indices for Detecting Changes in Benthic-Invertebrate Community Structure and Stream Quality. Archives of Environmental Contamination and Toxicology, 39, 469-479. http://dx.doi.org/10.1007/s002440010129

[104] Haase, R. and Nolte, U. (2008) The Invertebrate Species Index (ISI) for Streams in Southeast Queensland, Australia. Ecological Indicators, 8, 599-613. http://dx.doi.org/10.1016/j.ecolind.2007.08.005

[105] Whitehurst, I.T. and Lindsey, B.I. (1990) The Impact of Organic Enrichment on the Benthic Macroinvertebrate Communities of a Lowland River. Water Research, 24, 625-630. http://dx.doi.org/10.1016/0043-1354(90)90195-C

[106] Adamus, P. and Brandt, K. (1990) Impacts on Quality of Inland Wetlands of the United States: A Survey of Indicators, Techniques, and Applications of Community-Level Biomonitoring Data. EPA600/3-90/073, USEPA, Washington DC.

[107] Davies, S.P. and Tsomides, L. (2002) Methods for Biological Sampling and Analysis of Maine’s Rivers and Streams. 3rd Edition, Maine DEP LW0387-B2002, Augusta.

[108] Jacobsen, R.E. (2008) Midge (Diptera: Chironomidae and Ceratopogonidae) Community Response to Canal Discharge into Everglades National Park, Florida. Proceedings of the 16th International Chironomid Symposium, 13, 39-50.

[109] Wakelin, S.A., Colloff, M.J. and Kookana, R.S. (2008) Effect of Wastewater Treatment Plant Effluent on Microbial Function and Community Structure in the Sediment of a Freshwater Stream with Variable Seasonal Flow. Applied and Environmental Microbiology, 74, 2659-2668. http://dx.doi.org/10.1128/AEM.02348-07

[110] Watson, J.A.L., Arlington, A.H. and Conrick, D.L. (1982) Effect of Sewage Effluent on Dragonflies (Odonata) of Bulimba Creek, Brisbane. Marine and Freshwater Research, 33, 517-528. http://dx.doi.org/10.1071/MF9820517

[111] Davis, J.R. (1997) Revitalization of a North Texas River, as Indicated by Benthic Macroinvertebrate Communities. Hydrobiologia, 346, 95-117. http://dx.doi.org/10.1023/A:1002961931613

[112] Sprague, L.A., Clark, M.L., Rus, D.L., Zelt, R.B., Flynn, J.L. and Davis, J.V. (2006) Nutrient and Suspended-Sediment Trends in the Missouri River Basin, 1993-2003. US Geological Survey Scientific Investigations Report 2006-5231.

[113] Brown, J.B., Sprague, L.A. and Dupree, J.A. (2011) Nutrient Sources and Transport in the Missouri River Basin, with Emphasis on the Effects of Irrigation and Reservoirs. Journal of the American Water Resources Association, 47, 10341060 .

[114] Monda, D.P., Galat, D.L. and Finger, S.E. (1995) Evaluating Ammonia Toxicity in Sewage Effluent to Stream Invertebrates: A Multi-Level Approach. Archives of Environmental Contamination and Toxicology, 28, 378-384. http://dx.doi.org/10.1007/BF00213116

[115] Tavzes, B., Urbanic, G. and Toman, M.J. (2006) Biological and Hydromorphological Integrity of the Small Urban Stream. Physics and Chemistry of the Earth, 31, 1062-1074. http://dx.doi.org/10.1016/j.pce.2006.07.009

[116] Townsend, C.R., Uhlmann, S.S. and Matthaei, C.D. (2008) Individual and Combined Responses of Stream Ecosystems to Multiple Stressors. Journal of Applied Ecology, 45, 1810-1819. http://dx.doi.org/10.1111/j.1365-2664.2008.01548.x

[117] Ometo, J.P.H.B., Martinelli, L.A., Ballester, M.V., Gessner, A., Krusche, A.V., Victoria, R.L. and Williams, M. (2000) Effects of Land Use on Water Chemistry and Macroinvertebrates in Two Streams of the Piracicaba River Basin, Southeast Brazil. Freshwater Biology, 44, 327-337. http://dx.doi.org/10.1046/j.1365-2427.2000.00557.x

[118] Rosemond, A.D., Mulholland, P.J. and Elwood, J.W. (1993) Top-Down and Bottom-Up Control of Stream Periphyton: Effects of Nutrients and Herbivores. Ecology, 74, 1264-1280. http://dx.doi.org/10.2307/1940495

[119] Miltner, R.J. and Rankin, E.T. (1998) Primary Nutrients and the Biotic Integrity of Rivers and Streams. Freshwater Biology, 40, 145-158. http://dx.doi.org/10.1046/j.1365-2427.1998.00324.x

[120] Hillebrand, H. (2005) Light Regime and Consumer Control of Autotrophic Biomass. Journal of Ecology, 93, 758-769. http://dx.doi.org/10.1111/j.1365-2745.2005.00978.x

[121] Ward, A.K. (2006) Heterotrophic Bacteria. In: Hauer, F.R. and Lamberti, G.A., Eds., Methods in Stream Ecology, Academic Press, San Diego, 293-310.

[122] Garie, H.L. and McIntosh, A. (1986) Distribution of Benthic Macroinvertebrates in a Stream Exposed to Urban Runoff. Journal of the American Water Resources Association, 22, 447-455. http://dx.doi.org/10.1111/j.1752-1688.1986.tb01899.x

[123] Quinn, J.M. and Hickey, C.W. (1993) Effects of Sewage Waste Stabilization Lagoon Effluent on Stream Invertebrates. Journal of Aquatic Ecosystem Health, 2, 205-219. http://dx.doi.org/10.1007/BF00047770

[124] Pratt, J.M., Coler, R.A. and Godfrey, P.J. (1981) Ecological Effects of Urban Stormwater Runoff on Benthic Macroinvertebrates Inhabiting the Green River, Massachusetts. Hydrobiologia, 83, $29-42$.

http://dx.doi.org/10.1007/BF02187149 
[125] Medeiros, C., Leblanc, R. and Coler, R.A. (1983) An In-Situ Assessment of the Acute Toxicity of Urban Runoff to Benthic Macroinvertebrates. Environmental Toxicology and Chemistry, 2, 119-126. http://dx.doi.org/10.1002/etc.5620020113

[126] Beasley, G. and Kneale, P. (2002) Reviewing the Impact of Metals and PAHs on Macroinvertebrates in Urban Watercourses. Progress in Physical Geography, 26, 236-270. http://dx.doi.org/10.1191/0309133302pp334ra

[127] Strayer, D.L., Beighley, R.E., Thompson, L.C., Brooks, S. and Nilsson, C. (2003) Effects of Land Cover on Stream Ecosystems: Roles of Empirical Models and Scaling Issues. Ecosystems, 6, 407-423. http://dx.doi.org/10.1007/s10021-002-0170-0

[128] Booth, D.B. and Jackson, C.R. (1997) Urbanization of Aquatic Systems: Impacts, Solutions, and Prognoses. Northwest Environmental Journal, 7, 93-118.

[129] Walsh, C.R., Fletcher, T.D. and Ladson, A.R. (2005) Stream Restoration in Urban Catchments through Re-Designing Stormwater Systems: Looking to the Catchment to Save the Stream. Journal of the North American Benthological Society, 24, 690-705. http://dx.doi.org/10.1899/04-020.1

[130] Walsh, C.R., Sharpe, A.K., Breen, P.F. and Sonneman, J.A. (2001) Effects of Urbanization on Streams of the Melbourne Region, Victoria, Australia I: Benthic Macroinvertebrate Communities. Freshwater Biology, 46, 535-551. http://dx.doi.org/10.1046/j.1365-2427.2001.00690.x

[131] Richards, C., Johnson, L.B. and Host, G.E. (1996) Landscape-Scale Influences on Stream Habitats and Biota. Canadian Journal of Fisheries and Aquatic Sciences, 53, 295-311. http://dx.doi.org/10.1139/f96-006

[132] de Barruel, M. and West, N. (2003) A Benthic Macroinvertebrate Survey of Secret Ravine: The Effects of Urbanization on Species Diversity and Abundance. Water Resources Center Archives, Restoration of Rivers and Streams, eScholarship Repository Multi-Campus Research Unit, University of California, Sacramento.

[133] Harding, J.S. (1998) Stream Biodiversity: The Ghost of Land Use Past. Proceedings of the National Academy of Sciences of the United States of America, 95, 14843-14847. http://dx.doi.org/10.1073/pnas.95.25.14843

[134] Yoder, C.O., Miltner, R.J. and White, D. (1999) Assessing the Status of Aquatic Life Designated Uses in Urban and Suburban Watersheds. In: Everson, A., Ed., Proceedings of the National Conference on Retrofit Opportunities for Water Resource Protection in Urban Environments, EPA/625/R-99/002, USEPA, Chicago, 16-28.

[135] McMahon, G. and Cuffney, T.F. (2000) Quantifying Urban Intensity in Drainage Basins for Assessing Stream Ecological Conditions. Journal of the American Water Resources Association, 36, 1247-1261. http://dx.doi.org/10.1111/j.1752-1688.2000.tb05724.x

[136] Horner, R.R., Booth, D.B., Azous, A.A. and May, C.W. (1996) Watershed Determinants of Ecosystem Functioning. In: Roesner, L.A., Ed., Effects of Watershed Development and Management on Aquatic Ecosystems, American Society of Civil Engineers. New York, 251-274.

[137] May, C.W., Horner, R.R., Karr, J.R., Mat, B.W. and Welch, E.B. (1997) Effects of Urbanization on Small Streams in the Puget Sound Lowland Ecoregion. Watershed Protection Technician, 2, 485-494.

[138] Wang, L. and Kanehl, P. (2003) Influences of Watershed Urbanization and Instream Habitat on Macroinvertebrates in Cold Water Streams. Journal of the American Water Resources Association, 39, 1181-1196. http://dx.doi.org/10.1111/j.1752-1688.2003.tb03701.x

[139] Schueler, T.R. and Galli, J. (1992) Environmental Impacts of Stormwater Ponds. In: Wetlands Restoration Source Book, Washington Council of Governments, Washington DC, 242.

[140] Shaver, E., Maxted, J., Curtis, G. and Carter, D. (1994) Watershed Protection Using an Integrated Approach. In: Proceedings from Stormwater NPDES-Related Monitoring Needs, American Society of Civil Engineers, Mount Crested Butte, 435-459.

[141] Booth, D.B. and Jackson, C.R. (1997) Urbanization of Aquatic Systems: Degradation Thresholds, Stormwater Detention, and the Limits of Mitigation. Journal of the American Water Resources Association, 22, 1-20. http://dx.doi.org/10.1111/j.1752-1688.1997.tb04126.x

[142] Stepenuck, K.F., Crunkillton, R.L. and Wang, L.Z. (2002) Impacts of Urban Land Use on Macroinvertebrate Communities in Southeastern Wisconsin Streams. Journal of the American Water Resources Association, 38, 1041-1051.

[143] Morse, C.C., Hhuryn, A.D. and Cronan, C. (2003) Impervious Surface Area as a Predictor of the Effects of Urbanization on Stream Insect Communities in Maine, USA. Environmental Monitoring and Assessment, 89, 95-127. http://dx.doi.org/10.1023/A:1025821622411

[144] Short, T.M., Giddings, E.M., Zappia, H. and Coles, J.F. (2005) Urbanization Effects on Stream Habitat Characteristics in Boston, Massachusetts, Birmingham, Alabama, and Salt Lake City, Utah. American Fisheries Society Symposium, 47, 317-332.

[145] Weigel, B.M. and Robertson, D.M. (2007) Identifying Biotic Integrity and Water Chemistry Relations in Non-Wadea- 
ble Rivers in Wisconsin: Toward the Development of Nutrient Criteria. Environmental Management, 40, 691-708. http://dx.doi.org/10.1007/s00267-006-0452-y

[146] Wang, L., Robertson, D.M. and Garrison, P.J. (2007) Linkages between Nutrients and Assemblages of Macroinvertebrates and Fish in Wadeable Streams: Implication of Nutrient Criteria Development. Environmental Management, 39, 194-212. http://dx.doi.org/10.1007/s00267-006-0135-8

[147] Roy, A.H., Rosemond, A.D., Paul, M.J., Leigh, D.S. and Wallace, J.B. (2003) Stream Macroinvertebrate Response to Catchment Urbanization (Georgia, USA). Freshwater Biology, 48, 329-346. http://dx.doi.org/10.1046/j.1365-2427.2003.00979.x

[148] Karr, J.R. and Kerans, B.L. (1991) Components of Biological Integrity: Their Definition and Use in Development of an Invertebrate IBI. EPA 905-R-92-003, USEPA, Chicago.

[149] Karr, J.R. (1993) Defining and Assessing Ecological Integrity-Beyond Water Quality. Environmental Toxicology and Chemistry, 12, 1521-1531. http://dx.doi.org/10.1002/etc.5620120902

[150] Fore, L.S., Karr, J.R. and Conquest, L.L. (1994) Statistical Properties of an Index of Biological Integrity Used to Evaluate Water Resources. Canadian Journal of Fisheries and Aquatic Sciences, 51, 1077-1087. http://dx.doi.org/10.1139/f94-107

[151] Barbour, M.T., Stribling, J.B. and Karr, J.R. (1995) Multimetric Approach for Establishing Biocriteria and Measuring Biological Condition. In: Davis, W.S. and Simon, T.P., Eds., Biological Assessment and Criteria-Tools for Water Resource Planning and Decision Making, Lewis Publ., Boca Raton, 63-77.

[152] Hughes, R.M., Kaufmann, P.R., Herlihy, A.T., Kincaid, T.M., Reynolds, L. and Larsen, D.R. (1998) A Process for Developing and Evaluating Indices of Fish Assemblage Integrity. Canadian Journal of Fisheries and Aquatic Sciences, 55, 1618-1631. http://dx.doi.org/10.1139/f98-060

[153] Stewart, K.W. and Stark, B.P. (1993) Nymphs of North American Stonefly Genera (Plecoptera). 2nd Edition, University of North Texas Press, Denton.

[154] Wiggins, G.B. (1996) Larvae of the North American Caddisfly Genera (Trichoptera). 2nd Edition, University of Toronto Press, Toronto.

[155] Roth, N.E., Allen, J.D. and Erickson, D.L. (1996) Landscape Influences on Stream Biotic Integrity Assessed at Multiple Spatial Scales. Landscape Ecology, 11, 141-156. http://dx.doi.org/10.1007/bf02447513

[156] Kennen, J.G. (1998) Relation of Benthic Macroinvertebrate Community Impairment to Basin Characteristics in New Jersey Streams. US Geological Survey Fact Sheet FS-057-98. 